\section{An inclusive model suggestion in audio-visual media design in sampling of public ads: Is accessible media possible?}

\section{Kamu spotları örnekleminde görsel- işitsel medya ürünleri tasarımında kapsayıcı bir model önerisi: Engelsiz medya mümkün mü?}

\author{
Arzu Çelen Özer ${ }^{1}$ \\ Başak Kalkan ${ }^{2}$ \\ Gülfem Gürses ${ }^{3}$
}

\begin{abstract}
Instructive and informative contents of the Public Service Announcements (PSAs) need to reach to all segments of the society. Within this framework, the purpose of the research is to explain the importance of the narrative structure in the sight-disabled persons' access to the PSAs in terms of the up-to-date audio description criteria. In the study, the characters and the functions thereof in the narration have been reviewed within the frame of Labov \& Riesmann's narrative analysis constituents, and answer has been sought to the question, "Are the spatio-temporal constituents, motions, and the visual materials that depict the actions in connection with character definitions put into words for the sight-disabled persons?", by way of narrative analysis. While the 6 "Be Prepared for the Disasters!" PSAs are analyzed in terms of their narrative structures, the questions, "Who are the persons in the narrative? What are their functions in the narrative? What do these persons do in the narrative? Why do they do these things? What are the outcomes of
\end{abstract}

\section{Özet}

Kamu spotlarının, eğitici, bilgilendirici içerikleri ile toplumun tüm kesimlerine ulaşması gerekmektedir. $\mathrm{Bu}$ çerçevede araştırmanın amac1, görme engelli bireylerin kamu spotlarına erişiminde anlatı yapısının önemini güncel sesli betimleme kriterleri çerçevesinde belirtmektir. Anlatıdaki karakterlerin ve işlevlerinin ne olduğu, Labov ve Riesmann'in anlatı analizi bileşenleri çerçevesinde incelenmiş ve "Kamu spotunda anlatı oluşturulurken mekânsalzamansal bileşenler, hareketler, karakter tanımlarıyla bağlantılı fiilleri betimleyen görsel materyaller, görme engelli bireyler için kelimelere aktarılmakta midır?" sorusuna anlatı analizi ile yanıt aranmıştır. İncelenen altı "Afetlere Hazırliklı Ol!" kamu spotu, anlatı yapısı çözümlenirken "anlatıdaki kişiler kimler, bu kişilerin, anlatıdaki işlevi nedir, bu kişiler, anlatıda ne yapiyorlar, niçin yapiyorlar ve sonuçlar ne?" sorularına araştırmacilar dişında görsel iletişim, görsel- işitsel çeviri ve yazınsal iletişim alanında çalışan altı farklı uzmandan cevaplaması istenmiştir. Araştırma sonucunda,

\footnotetext{
1 Dr., Eskişehir Teknik Üniversitesi, Porsuk Meslek Yüksekokulu, Radyo ve Televizyon Teknolojisi Programı, acozer@eskisehir.edu.tr

2 Dr., Eskişehir Teknik Üniversitesi, Porsuk Meslek Yüksekokulu, Basım ve Yayın Teknolojileri Porgramı, basakkalkan@eskisehir.edu.tr

${ }^{3}$ Dr., Anadolu Üniversitesi, Açıöğretim Fakültesi, gulfemg@anadolu.edu.tr
} 
Çelen Özer, A., Kalkan, B., \& Gürses, G. (2020). An inclusive model suggestion in audio-visual media design in sampling of public ads: Is accessible media possible? Journal of Human Sciences, 17(1), 246-271. doi:10.14687/jhs.v17i1.5936

them?" are required to be responded by six different experts serving in the fields of visual communication, audio-visual translation, and narrative communication, other than the researchers. As a result of the research, it has been determined that, the PSAs are not designed as being suitable for the access of the sight-disabled persons, and two model proposals have been introduced at the end of the research by way of taking inclusive design criteria other than the conventional audio description criteria into consideration.

Keyword: Accessibility, Audio-Visual Description, Visual Impaired, Public Ad, Narrative.

(Extended English summary is at the end of this document) kamu spotlanının görme engelli bireylerin erişimine uygun olarak tasarlanmadığ 1 tespit edilmiş, geleneksel sesli betimleme kriterlerinin dışında kapsayıcı tasarım kriterleri dikkate alınarak iki model önerisi araştırma sonunda sunulmuştur.

Anahtar Kelimeler: Erişilebilirlik, Sesli betimleme, Görme Engelli, Kamu Spotu, Anlat1.

\section{Giriş}

Toplumsal hayat; bireylerin iletişimi, çatışması, dayanışması, baskı altına alınması ve denetlenmesi üzerine kurulu etkileşimli bir yapı içinde var olmaktadır. Toplumsal hayatı üretmenin, birlikte yaşamanın koşulu iletişimdir. Dewey iletişimi; "toplum olmanın önkoşulu" olarak belirtmektedir. Dewey "toplumun sadece iletişimle değil, iletişim içinde var olduğunu ve toplumun temelini iletişimin oluşturduğunu vurgular. ( Erdoğan \& Alemdar, 2010, s. 94) Toplumsal ilişki iletişim-etkileşim üzerine kurulur. İnsanlar arasındaki algılanı, istekleri, duyguları, düşünceleri, tutumları ve ihtiyaçları kısacası etkileşimi sağlayan araç iletişimdir. Teknoloji alanında yaşanan gelişme ve değişimler iletişim alanını etkileyerek kitle iletişimi kavramını ortaya çıkarmıştır. Teknolojik gelişmelerin sonucunda gazete, radyo, televizyon ve internet aracillğıyla insanlar bulundukları yer, yöre, ulus ve ulus sınırlarını aşarak çok daha büyük kitlelerle iletişim içinde olma şansını yakalamıştır. Radyo, televizyon, sinema ve internet teknolojisinin sağladığı uygulamaların kitlelere hitap edebilme özelliklerinden dolayı kitle iletişim arac1 ya da medya olarak adlandırılmışlardır. Kitle iletişim araçları, gazete, radyo, televizyon, sinema ve kablolu televizyon, mikro bilişim, sosyal medya gibi yeni iletişim teknolojilerini kapsamaktadır. (Mora, 2008, s.4) Medya, insanların iş hayatında toplumsal ve sosyal yaşamında önemli bir yere sahiptir. Mesajlar ve simgeler ileten bir sistem oluşturur.

Kitle iletişim araçlarının topluma hitap etmesi, vergilendirmelerle masraflarının topluma da maliyet getirmesi nedeniyle içerik biçimlendirmeden dağıtmaya kadar olan her aşamada bu araçlardan "sosyal sorumluluk" beklenmektedir. "Kitle iletişiminde sosyal sorumluluk; toplum çıkarına olan sorumluluk demektir”'(Erdoğan, 2013, s.187). Erdoğan ve Alemdar'in da belirttiği gibi Egemen yapısal-işlevselci görüşü yansıtanlar kitle iletişimini siyasal, ekonomik ve toplumsal sistemde, toplumu denetleyen, gözetleyen, insanları bilgilendiren, toplumsal kültürel mirasları aktaran bir yapı olarak sunarlar. (Erdoğan \& Alemdar, 2010, s.101)

Görsel ve işitsel bir araç olan televizyonun bireylerin günlük yaşamı içinde önemli bir yer edinmesi, toplumsal, sosyal sorumluluğa yönelik mesajların yoğun olarak televizyondan kitlelere ulaştırılmasını sağlamıştır. Televizyon özellikleri ve kullanım yaygınlığı nedeniyle kitlelere ulaşmada, haber vermede, bilgilendirmede, farkındalık yaratmada, etkilemede ve harekete geçirmede en önemli kitle iletişim aracı olarak görülmüştür. 
Çelen Özer, A., Kalkan, B., \& Gürses, G. (2020). An inclusive model suggestion in audio-visual media design in sampling of public ads: Is accessible media possible? Journal of Human Sciences, 17(1), 246-271. doi:10.14687/jhs.v17i1.5936

Özel sektör, sivil toplum kuruluşları ve devletin tanıtım ve sosyal sorumluluk çalışmalarının televizyondan yayını için yüksek bütçeler gerekmektedir. Bu nedenle kamu yararı taşıyan mesajların ücretsiz yayınlanmasının sağlandığı düzenlemeler yapılmıştır. (Bilgiç, 2016, s.27) Kamu hizmeti içinde yer alan bu düzenlemelerden biri de "kamu spotu "dur. 8 Ağustos 2012'de Radyo Televizyon Üst Kurulu (RTÜK) bir yönerge yayınlayarak kamu spotu yayınlanına açıklık getirmiştir. Kamu Spotları Yönergesinin tanımlar kısmında; "Kamu kurum ve kuruluşları ile dernek ve vakıf gibi sivil toplum kuruluşlarınca hazırlanan veya hazırlatılan ve Üst Kurul tarafindan yayınlanmasında kamu yararı olduğuna karar verilen bilgilendirici, eğitici nitelikteki film ve sesler ile alt bantları” şeklinde açıklanmışır"(Kamu Spotları Yönergesi). Kamu spotları, sosyal pazarlama ve sosyal reklam birbirine benzer özelliklere sahiptir. Ortak özellik kamu yararı hedeflemeleridir. Kitle iletişim araçları kullanılarak toplumdaki bireyleri etkilemek, topluma fayda sağlayacak tutum ve davranışı sağlamak amaçlanmaktadır. Bilgilendirme ve ikna bu programların çıkıs noktasını oluşturmaktadır. Çünkü bireylerde davranış değişikliği yaratılması ikna ile mümkün olmaktadır. Sosyal pazarlama ve kamu spotlarında konular bireylerin, toplumun sağlık, güvenlik, teknoloji, aile, toplumsal ve sosyal yaşama dayalı kurallar gibi kar amacı gütmeyen, kamusal farkındalığı arttırmayı amaçlayan bilgilendirici ve eğitici içeriklerden oluşmaktadır. RTÜK tarafindan 8/8/2012 yılında yürürlüğe sokulan Kamu Spotları Yönergesinin 4. Maddesinde de, "kamu spotlar1 ancak toplumu ilgilendiren ve yayınlanmasında kamu yaranı bulunan olay ve gelişmelere ilişkin konularda hazırlanır" ibaresi ile çerçevenin kamu yararı ile sınırlı olduğu belirtilmiştir. (Kamu Spotları Yönergesi Madde 4-(1) S:2) Sağlık, güvenlik, eğitim, teknoloji, ekonomi, hukuk, çevre, sosyal ve kamusal uygulamalar gibi konularda toplumun bilgilenmesi ve istenen davranışa yönelmesine yönelik ikna etmek için kamu spotlarından yararlanılır. Kamu spotlarında duygusal öğeler ve korku unsuru kullanılarak toplumda ikna yoluyla istenen davranışın uygulanması, yaygınlaşması hedeflenir. Kamu spotlarında hiçbir ticari iletişime yer verilemez. Sağlık, güvenlik suç, alkollü araç kullanma gibi konularda toplumun tutumunu yöneten önemli bir güç haline gelen kamu spotları genellikle bir toplumsal farkındalık kampanyasının parçasıdır. "Bu kampanyalar obezite ve kumar bağımlılı̆̆ına karşı toplumu bilgilendirir, eğitirler". "Bazı kampanyalar kamu spotlarında ünlüleri de kullanmaktadır"(Çakar, 2017, s.81).

Türkiye'de ilk kamu spotu 1979 yllında Süha Arın öncülügünde öğrencilerle hazırlanan "Dünya Sakatlar Yılı Kutlama Komitesi” projesidir. (Bilgiç, 2017, s.35) Toplumun ilk kez karşılaştığ1 bir uygulama olan katma değer vergisi ve alışverişlerde fiş alınması uygulaması kamu spotları ile tanıtılıp benimsetilmeye çalısılmıştır. "Bu spotlar '1 Dakika Kuşakları' adıyla yayınlanmıştır"(Bilgiç, 2017, ss.35-36). Türkiye'de kamu spotlarına yönelik ilk düzenleme, 1996 yllında 4207 sayllı Tütün Mamullerinin Zararlarının Önlenmesine Dair Kanunla gerçekleşmiştir. Tüm radyo ve televizyon yayıncılarına bu kanunla ilk defa 'zorunlu yayın' yükümlülügü getirilmiştir. İkinci düzenleme 2003 yılında yapılmıştır. Sosyal amaçlı reklamlar ve kamu yararına hazırlanan spotlar bu düzenlemede de bulunmaktadır. 3984 sayılı yasaya yapılan bir ekleme ile sosyal amaçlı reklam ve kamu spotlarının reklam sürelerine dâhil edilmeyeceği belirtilmiştir. Kamu spotları adından da anlaşılacağı gibi kamu hizmetine yönelik uygulamalar olarak yayınlanmaktadır. Kamuyu oluşturan toplumdaki bireyleri sağlık, güvenlik, eğitim, teknoloji, ekonomi, hukuk, çevre, sosyal ve kamusal uygulamalar gibi toplumsal konularda bilgilendirme, eğitme ve farkındalık yaratma amaciyla kamu spotları hazırlanmakta, zorunlu yayınlar olarak televizyonlardan yayınlatılmaktadır. Kamu spotlarında kimi zaman toplumun yakından tanıdığı kişiler yer alırken kimi zamanda bu spotlar dramatik bir anlatı yapısı içerisinde toplumdan kişiler ya da oyuncularla hazırlanmaktadır. Dramatik anlatı yapısı içerisinde hazırlanan kamu spotları, amaca yönelik ve mesajı içinde barındıran giriş, gelişme, sonucu olan öykülemeler biçiminde hazırlanmaktadır.

"Anlatı; en geniş tanımıyla, hikâyelerin nasıl anlatıldığıyla, hikâyelerde anlamın seyircinin anlayışına sunulmak üzere nasıl oluşturulduğuyla ilgilidir"'(Yaren, 2013, s.1). Anlatı yapısı içerisinde "zaman, uzam, karakterler, eylemler, olaylar, çatşma, neden-sonuç ilişkisi, anlatıcının konumu, seyircinin konumu" gibi temel kavramlar yer almaktadır. (Yaren, 2013, s.2) Anlatı metinlerinde 
Çelen Özer, A., Kalkan, B., \& Gürses, G. (2020). An inclusive model suggestion in audio-visual media design in sampling of public ads: Is accessible media possible? Journal of Human Sciences, 17(1), 246-271. doi:10.14687/jhs.v17i1.5936

anlatıya konu olan bir olay örgüsü vardır. Anlatıcı bu olay örgüsünü aktarmakla görevlidir. Olay örgüsü ve anlatıcı, anlatıların olmazsa olmaz değişkenleridir. (Sözen, 2008, s. 124) Anlatı yapısında öykü aynı zamanda öyküdeki karakterlerden birinin ağzından aktarilıyorsa bu "Homodigetik (öyküiçi) anlatı olarak tanımlanmaktadır. "Öyküde kahraman olarak yer almayan bir anlatıcı (dış ses gibi) bir kişi tarafından öykü aktarılıyorsa bu da "Heterodigetik" anlatı olarak tanımlanmaktadır"(Jahn, 2015, s.18). "Anlatıc1 anlatı söyleminin "sesi” dir"(Genette 1980'den Akt.Jahn, s.62). Anlatıc1 öykünün verdiği ders, mesaj ya da amacıyla ilgili yorumlar yapabilir(Jahn, 2015, s.62). Anlatıcının söylemi; anlatımın yapıldığ gönderilenle temas kurma, gönderileni bir şeye inanmaya ve yapmaya ikna etme ve kendi öznel duygu ve düşüncelerini ifade etme işlevleri üstlenebilir. (Jahn, 2015, s.62) Açı anlatıcı; dolaylı ya da dolaysız dinleyene seslenen, gerekli olan durumlarda işe yarayacak açıklamalar sunan, karakter ve olaylara karşı söylemsel bir konum sergileyen, yorumda bulunan anlatıcı olarak açıklanmaktadır. Kapalı anlatıcıda açık anlatıcının hiçbir özelliği yoktur. Dinleyiciye hitap etmez ve çağrı işlevi kaygısı yoktur. (Jahn, 2015, ss.63-64)

Murphy ve diğerlerinin (2013) sağlıkla ilgili konularda bilginin anlatıya dayalı öykü biçiminde verilmesinin bilgi, davranış ya da tutumda, etkiye sahip olup olmadığının araştırılmasına dayalı yaptıkları bir araştırmada; anlatının kanser hastalığına dayalı bilginin arttırlmasında ve davranış değişiminde etkili olduğu sonucuna ulaşılmıştır. Sağlık problemleri söz konusu olduğunda anlatı yönteminin problemin aktarımında ve çözümünde anlaş1ılılığ1 güçlendirecek etkili bir araç olacağ1 sonucuna varılmıştır. (Şardağı \& Yılmaz, 2017, s.91)

Toplumda kamu spotları ile verilmek istenen etkinin oluşması için mesajın hikâye anlatımı içinde yapılandırılmasının, izleyicilerin yaşam deneyimleri ile benzeşmesine ve içselleştirilmesine, gerçek yaşamda olabilirliğinin vurgulanmasına, örnek teşkil etmesine zemin hazırlayacaktır. "Öykülerin başarılı olması, ikna etmesi ya da başarısızlı̆̆a uğraması öykünün ahengi ve uygunlukla ilgilidir. Öyküdeki unsurların yarattığı denge "ahenk" olarak adlandırılmaktadır. Uygunluksa, öyküdeki unsurların birbiriyle uygun/alakalı biçimde bağlantılı olup olmadığılla ilgilidir”'(Sandıkçıŏlu, 2013, s.56).

Sandikçıŏlu ikna edici iletişim faaliyetinin öykü gibi “Öyküdeki insanlar kim?”, "Bu kişilerin öyküdeki işlevi nedir?", "Bu kişiler öyküde ne yapıyorlar?", "Niçin yapıyorlar?" ve "sonuçları ne?" şeklinde bölümler halinde tasarlanabileceğini belirtmektedir. (Sandıkçığlu, 2013, s.56)

Kamu spotlarının da formatlarına bakıldığında ikna edici iletişim için çoğunlukla toplumsal bilgilendirme, eğitme, farkındalık yaratma amacıyla anlatıya dayalı öyküleme şeklinde tasarlandıkları görülebilir.

Amacin topluma hizmet olduğu düşünüldügünde, kamu hizmeti adına yapılan ve yayınlanan kamu spotlarının tüm bireylere eşit şekilde ulaşması büyük önem arz etmektedir. Oluşması beklenen etkinin, değişmesi ya da yaygınlaşması hedeflenen davranışın toplumun geneline yayılabilmesi için verilmek istenen mesajın herkese ulaşması, herkes tarafindan içselleştirilmesi gerekmektedir. Kamu hizmetinin ilkeleri; eşitlik, süreklilik, değişkenlik, uyum olarak sıralanmaktadır. Eşitlik kamu hizmetinin ilkeleri arasında önemli bir yer tutmaktadır. Gözübüyük ve Tan'ın da ifade ettiği gibi sosyal devlet, sosyal adalet anlayışı içerisinde yer alan, kamu hizmeti hedefleyen devlet ve diğer kurumlar, bu hizmeti herkese eşit sunmakla yükümlüdür. Engelli bireylerin de toplumda farklı konumda bulunduğu düşünüldüğünde, devlet tarafindan yürütülen kamu hizmetlerinin onlara farklı şekilde uygulanarak ulaştırılması gerekmektedir (Çınarlı, 2008, s. 62).

Dünya Sağlık Örgütü (WHO) sağlık bağlamından engellilik kavramını; kişilerin vücut fonksiyonlarındaki eksiklik ya da işlevsizlik nedeni ile günlük yaşantıdaki normal aktivitelerini yerine getirememesi ya da sinırlı şekilde yerine getirilebilmesi olarak tanımlamaktadır. (WHO.1980.S:28) Türk Dil Kurumu güncel Türkçe sözlügünde de engellilik "engelli olma durumu" olarak tanımlanmaktadır. ( http://sozluk.gov.tr/)

"Özürlüler ve Bazı Kanun ve Kanun Hükmünde Kararnamelerde Değişiklik Yapılması Hakkında Kanun" da engelli; "Doğuştan veya sonradan herhangi bir nedenle bedensel, zihinsel, ruhsal, duyusal, sosyal yeteneklerini çeşitli derecelerde kaybetmesi nedeni ile toplumsal yaşama 
Çelen Özer, A., Kalkan, B., \& Gürses, G. (2020). An inclusive model suggestion in audio-visual media design in sampling of public ads: Is accessible media possible? Journal of Human Sciences, 17(1), 246-271. doi:10.14687/ihs.v17i1.5936

uyum sağlama, günlük gereksinimlerini karşılama güçlükleri olan korunma, bakım, rehabilitasyon, danışmanlık ve destek hizmetlerine ihtiyaç duyan kişis" olarak tanımlanmaktadır"(Köten \& Erdoğan 2014, s.24). Tıbbi açıdan "engellilik" "sağlıklı olma" tanımı karşısında yer alır. "Engeli olan birey" "engeli olmayan birey" karşısında dezavantajlı, yetersiz konumda kabul edilir. Çünkü engelli olan birey sağlıklı birey gibi bağımsızca hareket edemeyen, bedensel özelliklerini tam performanslı kullanamayandır. Yardım almadan günlük yaşantıdaki işlerini yerine getiremeyecek durumdadır. Sosyal yönden bakıldığında ise "engeli olan birey", sosyal yaşamı içinde düzenlemelerin yetersizliği sebebiyle engellenmiş, dezavantajlı konumda bırakılmış kişidir. Asıl olan toplumda herkesi kapsayıcı bir organizasyonun sağlanamamasıdır. (Burcu, 2017, ss. 108-109) Engellilik tıbbi olarak bedensel ve zihinsel olmak üzere iki başlık altında toplanmaktadır. Engelliliği bireysel ya da tıbbi eksiklik gibi gören anlayış, engellilerin eşit haklara ulaşımını engellemektedir. Bu anlayış engelli bireyleri hak sahipleri olarak kabul etmemekte aksine kendi sakatlıklarının mağduru durumunda bırakmaktadır. Birleşmiş Milletler Engelli Hakları Sözleşmesi'nde, engelliliğin yaratılan bir kavram olarak eşitlik temelinde topluma tam ve etkili katılma olanak tanımayan tutumlardan ve çevre koşullarından kaynaklandığ vurgulanmaktadır. Toplumda engelli olarak kabul edilen kişinin engeli aslında fiziki eksiklikten değil ihtiyaçlarının diğer bireylere göre değişkenliğinden kaynaklanmaktadır. Dünya Sağlık Örgütü 'de "engellilik" kavramına çevresel model örneğinde yaklaşmaktadır. Bu modelde; bireyin engelliliğini sağlık durumu değil çevre etkiler. "Örneğin bir elektrik kesintisinde görme yetisinden tamamıla yoksun biri evinde rahatlıkla dolaşabilir, çivi çakabilir. Eğer Braille kullanıcısıysa roman bile okuyabilir. Ancak görebilen biri bu görevleri kolaylıkla yapamaz. Bu örnekte bireyi engelli yapan çevredir"(Ünver \& Yamaçl, 2014, s.222). "Hayatı boyunca tekerlekli sandalyeye bağlı bir insan ile çocuğunun pusetini ya da yaşlı bir akrabasının tekerlekli sandalyesini itmek zorunda olan sağlıklı bir insanın aslında içinde bulundukları durum ve şartlar itibariyle birbirlerinden hiçbir farkları olmadığının da toplumun zihninde canlanabiliyor olması gerekir"(Ünver \& Yamaçl1, 2014, s.222). Bireyler, sivil toplum kuruluşları ve toplumun idaresinden sorumlu yöneticiler toplumsal yaşamı herkese eşit şartlarda sağlayacak kültürü yaygınlaştırmadığı, erişilebilirliği herkes için evrensel bir boyuta taşımadığ sürece, eşit haklardan ve koşullardan söz etmekte mümkün olamayacaktur.

Engelli olmak bireye ait olsa da ona ilişkin sorunlardan toplum olarak herkes sorumludur. Engellilik daha çok toplumun "engeli olan bireylerin" ihtiyaçlarını hesaplamadaki başarısızlı̆g ile ilişkilidir. "Engellilik sosyologlarının da belirttiği gibi toplum, engeli olan bireyi hastalığa sahip trajik bir durumdaymıs gibi düşündüğü için bu bireylerin olumsuz etiketlemelerle sosyal yaşamın içinde yer almalarına neden olmaktadır. Bu tür olumsuz düşünceler 'engeli olan bireylerin sosyal ilisskilerini olumsuz olarak etkilerken onların sosyal yaşamlarının hemen her alanında dışlanma, ayrımcılık, izolasyon, yalnızlaştırılma şeklinde dezavantajlı konumlanmalarına yol açmaktadır"'(Burcu, 2017, s. 109). Toplum yaşamı içinde yer alan düzenlemeler engeli olmayan bireylere yönelik gerçekleştiği için engelli olarak tanımlanan, toplumun önemli bir grubunu oluşturan bireyler kendilerine toplum yaşamı içinde yeterli ölçüde yer bulamamaktadır. Burcu; "engelliliğin daha çok toplumun engeli olan bireylerin ihtiyaçlarını hesaplamadaki başarısızlı̆̆ ile ilişkili olduğunu”" vurgulamaktadır(Burcu, 2017, s. 109). Kişinin sağlık ve yeti kaybı doğuştan olabileceği gibi sonradan da olabilir. Günlük yaşamını, fiziksel aktivitelerini tam ve kimseye muhtaç olmadan yürüten bir kişi sonradan sağlikla ilgili bozulmalar ya da yaşllık sebebiyle, yürütemez hale gelebilir. Dolayısıyla yaşam içindeki düzenlemelerin engelleri aşacak şekilde tasarlanması, uygulanması herkes için gerekli ve önemlidir. Engel aslında günlük yaşamın idamesinde ortaya çıkan bir sorundur ve eğer bu sorunun çözümüne yönelik çalışmalar, uygulamalar ve yasalar çıkarılırsa engel ortadan kalkacak ya da yaşamı olumsuzlaştırmayacak bir durum olacaktır. Bu tür düzenlemeler, uygulamalar erişilebilir bir toplum yaşamını olanaklı hale getirerek, toplumda her bireyin eşit, sorunsuzca bireysel ve toplumsal haklarına ulaşmasının temelini oluşturacaktır. 
Çelen Özer, A., Kalkan, B., \& Gürses, G. (2020). An inclusive model suggestion in audio-visual media design in sampling of public ads: Is accessible media possible? Journal of Human Sciences, 17(1), 246-271. doi:10.14687/ihs.v17i1.5936

Özgül; erișilebilirliği, tüm haklardan, hizmetlerden herkesin sıkıntı yașamadan eșit koșullarda faydalanabilmesi, toplumsal yaşamın tüm alanlarına tam ve etkin şekilde katılabilmesi olarak açıklamaktadır.(Özgül, 2015, s.62) Erişilebilirliği bağımsız bir hükümle düzenleyen ilk sözleşme BM Engelli Hakları Sözleşmesi'dir. BM Engelli Hakları Sözleşmesinde; engellilerin toplumun refah ve çeşitliliğine yaptıkları, yapabilecekleri katkılar olduğu vurgulanmış bu nedenle de fiziki, sosyal, kültürel ve ekonomik her ortama ulaşım, sağlık, eğitim, bilgi ve iletişime erişim gibi hizmetlerin herkese eşit olarak sağlanması gerektiği vurgulanmıştır. (BM Engelli Haklanı Sözleşmesi) Engelleri ortadan kaldırıcı adımlar atmak, erişilebilir bir toplum düzeni yaratmak hem hükümetlerin hem de vatandaşların sorumluluğundadır. Herkes erişilebilir bir toplum düzeni için üstüne düşen sorumluluğu yerine getirmekle yükümlüdür. Ancak bu şekilde eşit haklardan ve firsatlardan bahsedilebilir. "Erişilebilirlik, sistemi kullananların sisteme girdi ve çıktısını sağlayan çevresel karakterlerle ilgilidir. Kullanılabilirlik ise sistemde, amaçlanan işlevleri yerine getirmek veya elde etmek için hedefleri etkili, verimli kullanımılla ilgilidir”'(Hersh, 2008, s.1038).

Uluslararası düzeyde engelli bireylerin haklarına değinen ilk düzenleme 1971 yllinda yapılmıştır. Bu düzenleme Birleşmiş Milletler tarafindan kabul edilen Zihinsel Engellilerin Hakları Beyannamesidir. (Yıldız \& Gürler, 2018, s.243) Sonraki yıllarda çalışma, eğitim, sağlık, rehabilitasyon, erişilebilirlik ve istismar gibi pek çok konuda engellilere yönelik düzenleme yapılmıştır. Birleşmiş Milletler Engelli Hakları Sözleşmesi (BMEHS) ilk büyük insan hakları sözleşmesidir. (Yıldız \& Gürler, 2018, s.243) Türkiye 30 Mart 2007'de Birleşmiş Milletler Engelli Hakları Sözleşmesi'ni imzalamıştır. Bakanlar Kurulu ise 5825 sayılı Kanun'a dayanarak onay işlemini 2009 yılının Mayıs ayında gerçekleştirmiştir. (Gül, 2015, ss. 40-41)

Türkiye'de bu konudaki ilk yasal düzenleme 1930 yllnda yapılan 1580 sayılı Belediyeler Kanunu ile gerçekleşmiştir. Daha sonra engelli bireylere yönelik daha fazla eşitlikçi yaşamın zeminini hazırlayacak bazı düzenlemelerde yapılmıştır. (Yıldız \& Gürler, 2018, s.244) Türkiye, 2000'li yıllarla birlikte engelliliğe insan hakları temelli yaklaşmışır. Engelli bireylerin bağımsız yaşayabilmeleri, toplumsal hayata tam ve aktif katılabilmeleri, ulaşım, eğitim, sağlık, bilgi, iletişim teknolojileri ile kamusal hizmetlerden eşit koşullarda faydalanabilmeleri için sosyal devlet anlayışı içinde hem yöneticilere hem de toplumu oluşturan kişi ve sivil toplum kuruluşlarına önemli görevler düşmektedir. Erişilebilirlik adına yasal ve hukuki düzenlemeleri arttırmak, bunların uygulanabilmesine yönelik yaptırımlar oluşturmak, bunların takibini sağlamak eşit haklar ve yaşamsal ihtiyaçlar açısından oldukça önemlidir. Sosyal devlet anlayışı içerisinde erişilebilirlik çalışmalarının olması kaçınılmaz görünmektedir. Çünkü kamu hizmeti tüm vatandaşların kamusal fayda sağlayacak tüm haklara eşit erişimini içeren bir kavram olarak düşünülmelidir. Devlete bağlı kurumların vatandaşın yararına politikalar üretmesi, hizmetlere erişimin eşit ve tam gerçekleşmesi, demokratik ve çoğulcu uygulamaların yürütülmesi kamu hizmetini sağlarken aynı zamanda eşit haklar bağlamında erişilebilirliği de gündeme almayı zorunlu kılmaktadır. Çünkü sosyal devlet denildiğinde, toplumda yer alan, büyük bir azınlığı oluşturan engelli vatandaşlarına erişilebilir, yaşanabilir, eşit haklara sahip oldukları bir dünya hazırlama sorumluluğunda ve bilincinde olan devlet akla gelmektedir (Çınarlı, 2008, s.63). Devletin yürüttüğü kamu hizmetlerinin erişilebilir hale getirilmesi toplum yaşamında engelleri ortadan kaldıracak örnek ve önemli bir adım olacaktır. Toplumda erişilebilir bir toplumsal düzen sağlanması, fiziksel olarak yeti kaybı nedeniyle yaşamını sürdürmek zorunda olan bireylerin toplum hayatında daha adil ve eşit haklardan yararlanması için ön koşuldur.

Kamu hizmetine dayalı kamu spotlarının da herkese eşit ulaşması için herkesin kamu spotlanına erişebilmesi gerekmektedir. Engelli bireyler arasında yer alan duyma ve görme engelli bireylerin kitle iletişim araçları yoluyla görsel-işitsel medya ürünlerine ulaşabilmesi, erişilebilir olmak koşulunu gündeme getirmektedir. Görsel ve görsel işitsel medya olarak adlandirılan radyo, TV, gazete ve yeni medya olarak adlandırılan internete dayalı ortamlarda görme, işitme ya da hem görme hem de işitme sorunu yaşayan bireyler için erişilebilir medya ürünleri tasarlanması eşitlik, erişilebilirlik açısından önemli ve gerekli bir durumdur. Özellikle kamu hizmeti adına yapılan, kamu yararı amaçlanan kamu spotlarında hedefin toplumu bilinçlendirme, eğitme, ikna yoluyla istenen 
Çelen Özer, A., Kalkan, B., \& Gürses, G. (2020). An inclusive model suggestion in audio-visual media design in sampling of public ads: Is accessible media possible? Journal of Human Sciences, 17(1), 246-271. doi:10.14687/jhs.v17i1.5936

olumlu davranışa yöneltme olduğu düşünülürse, en başta bu programlanın erişilebilir olarak hazırlanmasının zorunlu olduğu anlaşılmaktadır. İkna için gerekli motivasyonun sağlanması ancak kamu spotunda verilen mesajın anlaşılabilmesi ile gerçekleşebilir. Erişilebilir hazırlanmayan spotların, işitme ve görme engelli bireyler için mesaj verme ya da bilgilendirip ikna yoluyla olumlu tutum geliştirme amacının gerçekleşebilmesi, oldukça zordur. Bu nedenle kamu spotlarının görme ve işitme engelli bireylere yönelik tasarlanması ve hazırlanması gerekmektedir. Özellikle görsel ortamlar için hazırlanan kamu spotlarında mesajın ağırlığı görüntü üzerine yüklendiğinde, görme engelli bireylerin bu mesaj1, mesajın yaratmayı amaçladığ1 etkiyi kaçırması kaçınılmazdır. Görsel alg1, görsel araçla verilmek istenen mesajın alınmasında önemli bir unsur teşkil eder ve görme engelli bireylerin mesajı algılamasını zorlaştırıcı bir durum yaratır. Görme yetisini kaybetmiş bireyler için televizyonda, görsel medyada diğer algıları harekete geçirici, anlaşılırlı̆̆1 sağlayıcı kamu spotlanı hazırlamak, verilen mesajın alınması, istenen etkinin yaratılması için gerekli bir çalışma olacaktır. Radyo ve Televizyon Üst Kurulu 'da bu doğrultuda 2019 yllında bir çalıştay gerçekleştirmiştir. "Sağırların, İşitme ve Görme Engellilerin Görsel-İşitsel Medya Hizmetlerine Erişiminin İyileştirilmesi Çalıştayı” yeni engellilik kültürünün inşasında önemli bir adım olarak görülmektedir. Çalıştay görsel- işitsel medyada erişilebilirliğin amacıyla gerçekleştirilmiştir. Sonuç bildirgesinde amaç ve temel ilkeler, talep edilen uygulamalar, altyap1 ve teknoloji ile ilgili beklentiler ifade edilmiştir. $\mathrm{Bu}$ çalıştay sonrasında 30915 sayılı "Sağırların, İşitme Ve Görme Engellilerin Yayın Hizmetlerine Erişiminin İyileștirilmesine İlişkin Usul Ve Esaslar Hakkında Yönetmelik" 11/10/2019 tarihinde yürürlüğe girmiştir. 2019 yllında yürürlüğe giren yönetmelik ile engelli bireylerin görsel-işitsel medyaya erişimleri noktasında önemli bir adım atıldı̆̆ı dikkat çekmektedir. Çalışmanın örneklemini oluşturan kamu spotları açısından ilgili yönetmelik incelendiğinde; kamu spotu başvurularında, "ayrıntılı altyazı, işaret dili ve sesli betimleme çeviri türlerinden en az birinin bulunması gerekliliği, bu çeviri türlerinden herhangi birini bulundurmayan kamu spotu başvuruları Üst Kurulca reddedilebilir", denilmektedir. Kamu spotlarının bu yönetmelik ile birlikte görsel ve işitsel anlamda engelli bireyler tarafindan erişilebilir ya da daha da önemlisi kapsayıcı tasarlanması zorunlu hale gelmiştir. Görme engelli bireylerin görsel- işitsel kamu spotlarına erişiminin temelinde sesli betimleme ya da diğer adıyla görsel- işitsel çeviri bulunmaktadır.

\section{Sesli Betimleme (Görsel- İşitsel Çeviri)}

Engelli bireylerin görsel- işitsel medya araçlarına erişimine ilişkin 2019 yllında yürürlüğe giren yönetmelik çerçevesinde görsel- işitsel medya araçlarının erişilebilir tasarım ilkelerine göre yapılandırılması önemli hale gelmiştir. Erişilebilir görsel- işitsel medya araçları tasarım ilkeleri bu çalışma kapsamında görme engelli bireyler ile sınırlandırılmaktadır. Bu çerçevede görme engelli bireylerin görsel- işitsel medya ürünlerine erişiminde sesli betimleme yöntemi kuşkusuz en etkili yöntem olarak dikkat çekmektedir.

Görsel- işitsel çeviri, görmeye dayalı ürünlerde diyaloglar dışında kalan bölümlerin bir dış ses aracillğıyla betimlenmesidir. Olay örgüsü içinde yer alan mekân, zaman ve karakterlerin, sesin olmadığı yerlerin dış ses tarafindan sözlü betimlenerek görünüm ve duygular anlatılmaktadır. Sesli Betimleme Derneği tarafindan yapılan tanımlamaya göre sesli betimleme, "görsel olan her şeyin görme engeller için diyaloglar haricindeki bölümleri dolduran bir dış sesin görsel- işitsel çeviri tekniği ile özel kurgusunun yapılması, görme engellilerin kimseden yardım almadan tek başlarına bu eserleri seyredebilmelerine olanak sağlayıcı tekniklerin bütünüdür”( www.sebeder.org).

Medya ürünlerinin artan çeşitliliği ve 21. Yüzyılda engelli kültürünün yeniden inşası çalışmaları ile görme engelli bireylere yönelik çeviri çalışmalarının da tanımı değişmiştir. Amaç, görsel- işitsel bir ürünü çevirmek olduğu için geleneksel çeviriye kıyasla bilgilerin aynı olmadığ1 gerçeği dikkat edilmesi gereken en önemli unsurdur. "Görme engelliler için televizyon, sadece bir bilgi kaynağ1 değil, aynı zamanda sosyal düzeyde önemli bir popüler ortamdır. Yasal düzenlemeler çerçevesinde bugün sesli anlatılan filmlere yönelik talep artmıştır. Bu artan talep, görsel- işitsel çevirinin kalitesi 
Çelen Özer, A., Kalkan, B., \& Gürses, G. (2020). An inclusive model suggestion in audio-visual media design in sampling of public ads: Is accessible media possible? Journal of Human Sciences, 17(1), 246-271. doi:10.14687/jhs.v17i1.5936

ölçmek için yöntemler geliştirilmesini de zorunlu kılmaktadır”( Jekat \& Prontera \& Bale, 2015, s.446-464).

Görsel- işitsel çeviri kriterleri incelendiğinde, temel kriterler şu şekilde sıralanabilir. Görselişitsel çeviride kelime seçimi, telaffuz, diksiyon konusunda hiçbir hata olmamalıdır. Amaçlanan çıtıtları için gerekli olan içerik birincil derecede önemlidir. Hem açıklama içeriği hem de seslendirme, programin stiline, tonuna ve hızına uymalıdır. Hedef kitlenin beklentileri, nesnel bir aktarım ve sadelik önemlidir. Tüm bu kriterleri kapsayan son kriter ise, eşit erişimdir. "Eşit erişim, programin anlaminin ve amacinin aktarilmasinı gerektirir" (https://www.3playmedia.com/resources/popular-topics/audio-description/\#examples).

Görsel- işitsel çeviri yaparken, önemli noktalara odaklanmak gereklidir. Örneğin, kimin sahnede veya ekranda olduğunu, kimin konuştuğunu, sahne - girişler ve çıkışlar, dekor, aydınlatma, kostümler, yüz ifadeleri, hareketler, eylemler, tavırlar, jestler gibi görsel- işitsel tasarımın bütün öğeleri önem kazanmaktadır. Kullanıcıların içeriği tüketebilmesi için açıklamaya güvenmesi gerekir. Açıklamanın kafa karıştırıcı ve yanıltıcı olmaması bu noktada önemlidir. Yüksek kaliteli tanımlama, medyayı daha iyi ve kolay anlaşılır hale getirerek geliştirmekte ve tamamlamaktadır. Görsel- işitsel çeviri sadece görme engelli bireyler için eşit erişim imkânı sunmamaktadır. Görsel- işitsel çeviri otizm spektrumlu bireylerin de duygusal ve sosyal ipuçlarını anlamalarını kolaylaştırmaktadır. Her hangi bir görme engeli olmayan bireyler için de görme eylemini gerçekleştiremeyecekleri ortamlarda videoları deneyimleme esnekliği sunmakta ve dil gelişimini sağlamaktadır. Yapılan çalışmalar göstermektedir ki, dinleme, dil öğrenmede ve onu uygun eylem ve davranışlarla ilişkilendirmede önemli bir adımdır. Bu çerçevede işitsel öğrenenleri için sesli anlatım etkili ve verimli bir öğrenme aracıdır. Öğrencilerin \% 20-30'u bilgiyi en iyi şekilde sesli anlatımla gerçekleştirdiklerini ifade etmektedirler. Sesli anlatım, gözden kaçırılan tüm öğeleri de görüntüleyenlere sunarak önemli avantajlar sağlamaktadır(http://docenti.unimc.it/catia.giaconi/teaching/2017/17069/files/corsosostegno/audiodescrizioni).

Kızllaslan ve Sözbilir tarafindan 2017 yılında çalışma göstermektedir ki, Kahn ve Rozin tarafindan 1975 yllinda yapilan ve Cornoldi, Cortesi ve Preti tarafindan 1991 yllinda yapılan her iki çalışmada da görme duyusunu tamamen kaybetmiş bireylerin farklı duyu organları yardımı ile topladığ1 verilerle zihinlerinde nesneleri alg1layabildiklerine ilişkin güçlü veriler elde edilmiştir. Yapılan çalışmalara göre, gören bireyler gibi beynin görmeden sorumlu alanı aktiftir ( Kızılaslan \& Sözbilir, 2017).

Ekran Çevirisi veya televizyon çevirisi olarak bilinen Görsel-İşitsel Çevirinin bilimsel çalışmalarda öncülleri, Dirk Delabastita, Yves Gambier, Jorge Díaz Cintas ve Delia Chiaro olarak sıralabilir. Ancak halen küresel düzeyde etkilerine ilişkin çalışmalarda eksiklikler bulunmaktadır. Delia Chiaro görsel- işitsel tekniklerin kullanımına bağlı olarak Avrupa'yı iki kategoriye ayırmaktadır. İngiltere, Benelüks, İskandinav ülkeleri, Yunanistan ve Portekiz altyazı kategorisine girerken, Orta ve Güney Almanya'dan İspanya'ya kadar uzanan Avrupa ülkeleri (Fransa, İtalya, Almanya ve ayrrca Avusturya) dublaj kategorisi içinde ele alınmaktadır. Daha sonra Avrupa ülkelerinin ötesine geçerek İsrail, Hong Kong veya Tayland gibi altyazıların tercih edildiği ülkeler olurken, dublajın güçlü olduğu, ülkeler Latin Amerika, Çin ve Japonya olduğu görülmektedir (Chairo, 2009).

Sesli tanımlamanın amacı, atmosferin ve bir filmin içeriğinin sözlü açıklamalarla iletilmesidir; bu, karmaşık bir multimedya metninin (film) yalnızca duyulabilir bir metne indirgenmesi anlamına gelir. Sesli metnin tamamı iki tür akustik işaretten oluşur: birincisi, filmin sesi (diyalog, arka plan sesi, müzik) ve ikincisi görsel içeriğin tanımı. Açılamalar diyaloglar arasında konumlandırılmalı ve filmdeki sesleri boğmamalıdır. Bu, Almanya'da sesli tanımlamanın öncüsü olarak kabul edilen Dosch ve Benecke tarafindan desteklenmektedir. Dolayısıyla açıklama alanı sınırlıdır ve kısa bir süre içinde büyük miktarda bilginin iletilmesi (ve anlaşılması) gerekir. (Jekat \& Prontera \& Bale, 2015, ss. 446-464). 
Çelen Özer, A., Kalkan, B., \& Gürses, G. (2020). An inclusive model suggestion in audio-visual media design in sampling of public ads: Is accessible media possible? Journal of Human Sciences, 17(1), 246-271. doi:10.14687/ihs.v17i1.5936

Benecke’ye göre görsel çeviri, mümkün olduğunca fazla bilgi sağlamayı amaçlayan ve aynı zamanda filmlerin veya oyunların görsel boyutunu seslendirirken kısa ve kesin olmaya çalışan bir anlatım tekniğidir (Benecke 2007) . Nihai amacı bir anlatıcı tarafından yüksek sesle okunmaktır. Benecke'ye göre, başlamadan önce sorulması gereken üç kritik soru vardır: Bunlar, ne tanımlanmalıdır, ne zaman tanımlanmalıdır ve nasıl tanımlanmalıdır.

Sesli olarak tanımladığınız hedef kitle burada çok önemli faktör olarak dikkat çekmektedir. Farklı seviyelerde körlük ve görme bozukluklarına göre bu soruların cevaplarını vermek önemlidir. Bir görsel ürünü betimlerken, görme derecesi, renklerinin betimlenmesi veya klyafetlerin betimlenmesi gibi noktalarda daha iyi bir resim elde etmeleri açısından önem kazanmaktadır.

Bir diğer önemli husus ses unsurudur. Unutulmamalıdır görsel çeviri okunması gereken bir metindir. Görsel-işitsel ürüne bağlı olarak, bazı sesler diğerlerinden daha iyi olabilir. Örneğin, bir film ya da belgesel seslendirilirken yetişkin bir ses, çocuklara yönelik bir tasarımda ise, çocuk seslerin kullanılması önemlidir. Bir diğer önemli faktör anlatımın hızı ve anlaşılırlığıdır. Tüm dillerde ortak bir karakter ve saniye ilişkisi kurulamasa da kabul edilen, anlatıcının normal hızda senaryoyu anlaşılır bir şekilde okumak için yeterli zamana sahip olması gerektiğidir. Konuşma hızı yapılan çalışmalarda ideal olarak dakikada 160 kelime olarak belirlenmiştir. Bir diğer önemli nokta ise, görsel çeviride çok fazla bilgi olması kadar, hiçbir anlatımı olmayan uzun zaman aralıklarıdır. Aenor ve Ofcom'un çalışmaları göstermektedir ki hedef kitleyi strese itmektedir. Ofcom'un önerisi bu noktada sessiz sürenin 2 dakikayı geçmemesidir. İyi mikrofon tekniği kullanımı da önemli noktalar arasındadır. Ani ve gereksiz ses değişiklikleri de medya ürününün tüketilmesinde sorunlara neden olmaktadır Ses zirve frekanslarının kaydedilerek yapılan Colins 2000 ve Colins \& Missing 2003 çalışmaları göstermektedir ki kadın ve erkek ses çekiciliği birbirinden farklıdır. İnce sesli kadınlar daha çekici bulunurken, kalın sesli erkeklerin ses çekiciliği açısından daha çekici bulunduğu saptanmıştır (Collins \& Missing, 2003). Cara ve arkadaşları tarafindan 2012 yllında yapılan çalışma ise oy verme davranışı ve ses arasındaki ilişki üzerinedir. Kalın ses rengine sahip politikacıların, kamuoyu tarafından daha güvenilir bulundukları tespit edilmiştir. Görsel-işitsel bir araç olan televizyon ve sinemada ses, görüntü ile verilmek istenen mesajı güçlendiren bir yapım öğesi iken aynı zamanda anlatım görevini de üstlenmektedir. Ses izleyiciye, yol gösteren bir yapım öğesi olarak çalışmaktadır.

Kızılaslan ve Sözbilir'in 2017 yılında yaptıkları çalısmada ses ayrımı konusunda da Gougoux ve arkadaşlarının yaptuğı çalışmalar ile Hötting, Rösler ve Röder tarafindan yapılan çalışmalara yer verilmiştir. "Gougoux ve arkadaşları şiddet bakımından birbirine yakın olan iki sesin ayrımı üzerine yaptığ çalışmada erken dönem görme yetisini kaybedenlerin görenlere göre daha iyi ayrım yapabildiğini tespit etmiştir. Hötting, Rösler ve Röder tarafindan erken dönem, geç dönem ve doğuştan görme yetisini kaybetmiş bireyler ile gören bireylere dayalı bir çalışma yapılmışıtır. $\mathrm{Bu}$ çalışmada sesin üç özelliğinin "-tını ayrımı, ses hafızası (pek çok ses dinletip benzer olan seslerin gruplama) ve ses yüksekliği ayrım1- kıyaslanmıştır. Bütün durumlar için geç dönem görme yetersizliği olanlarla gören bireyler aynı performansı sergilerken, doğuştan görme yetersizliği olan ile erken dönem görme yetersizliği olanlarda tını ve ses yüksekliğini ayırt etme performanslarının diğer gruptakilerden daha iyi olduğu ve ses hafizası özelliğinin ise bütün gruplarda aynı olduğu tespit edilmiştir. Bu durum bize algıda keskinlik düzeyinin özellikle doğuştan ve geç dönem görme yetersizliği olanlarda daha belirgin olduğunu, ses hafızası gibi üst bilişsel işlemlerde ise tüm gruplarda hiçbir farklılığın olmadığını göstermektedir” (Kızılaslan \& Sözbilir, 2017).

Kelime algılama kapasitelere bakımından görme engelli bireyler incelendiğinde, görmeyen bireyler dakikada 25 kelime algilayabilirken; gören bireylerde bu 8- 10 kelimedir. Sesin konumu ve mesafesini belirlemede görme yetersizliği olan bireylerin, görenlere göre daha üstün performans sergiledikleri görülmektedir (Hertrich vd., 2009).

Amedi ve arkadaşlarının kelime algılama kapasitesine ilişkin yaptıkları çalışmada, görme engelli bireyler ve gören bireylere aynı uzunlukta bir kelime listesi verilmiştir. Sonuçlar göstermektedir ki, görme engelli bireyler sırasına göre daha fazla kelimeyi tekrarlamaktadırlar. Röder ve arkadaşları ise yaptıklanı çalışmada, görme engelli bireylerin kelime algılama kapasitelerinin yüksek olmasının 
Çelen Özer, A., Kalkan, B., \& Gürses, G. (2020). An inclusive model suggestion in audio-visual media design in sampling of public ads: Is accessible media possible? Journal of Human Sciences, 17(1), 246-271. doi:10.14687/jhs.v17i1.5936

nedenlerini araştırmışlardır. Yapılan araştırma sonuçlarına göre görme engelli bireylerin gelişmiş anlamsal işleme süreçleri nedeni ile daha fazla kelime alg1lama kapasitesine sahip oldukları tespit edilmiştir. ( Kızılaslan \& Sözbilir, 2017)

Bu çerçevede görsel çevirinin üretim süreci kadar, üretilen metnin aktarımı da önemlidir.

Yapılan çalışmalar çerçevesinde görsel- işitsel çevirinin dilinde olması gereken başlıca özellikler şunlardır:

- Açıklamanın anlaşılması için basit, anlaşılır ve kısa olması,

- Açıklayıcı, doğru ve uygun bir dilin kullanılması,

- Bir karakteri tanımlayana kadar mümkün olan her yerde tam cümleler kullanılması,

- Kelime bilgisinin içerikle eşleştirilmesi,

- Gerekli olmadıkça teknik terimlerden kaçınılması,

- Rahatsız edici veya ırkçı terimler kullanılmaması ancak uygun olan yerlerde etnik kökenin tanımlanmasi,

- Fiil kelime hazinesinin betimleyici açısından genişletilmesi,

- "Görüyoruz" gibi tanımlamalardan kaçınılması ve

- Dinleyiciler için neyin gerçek, neyin hayal olduğunun farkında olunmasıdır.

Joel Synder editörlüğünde 2010 yllında yayınlanan sesli betimleme ortak ilkeleri ve iyi örnekler kitapçığında, görsel çeviride, görülenlerin kişisel yorum yapmadan açıklanması gerektiği vurgulanmaktadır. Sunumun görsel- işitsel medya ürününün içeriği ile uyumlu olması önemlidir. Her duraklamayı doldurmak etki ve verimliliği düşürmektedir. Açıklamaların şimdiki zamanda yapılması ve gören izleyicilerle aynı duygunun deneyimlenmesi çevirinin başarısını ortaya koyan unsurlardır. Unutulmaması gereken nokta, iyi çevirinin dikkati çeviriye değil, medya ürününe yönlendiren çeviri olmasidir (Synder, 2010).

K1lavuzlara göre, betimlenmek üzere seçilecek ögeler üç kümede toplanabilir: (i) imgeler, (ii) sesler (anlaşılması güç sesler, yabancı dildeki sözcükler) ve (iii) (ekranda) görüntülenen yazılar (jenerik, yer ve zaman gösteren başlıklar, altyazılar, vb.). Anlamlı seslerin ve ekran yazılarının yanısıra imgeler betimlenerek, SB kullanıcılarına anlatıyla ilgili "kim, kiminle, nerede, ne zaman, ne yapıyor?" sorularının yanıtlanı verilir. Gerçekten de Birleşik Krallık'ta gerçekleştirilen Sözcüklerle Televizyon projesi kapsamında 91 filmin sesli betimlemelerinden oluşan çalışmada, ağırlıklı olarak şu ögelerin betimlendiği saptanmıştır; karakterlerin görünüşleri, duygusal durumları, kişilerarası ilişkileri, nereye baktıkları ve karakterlerle nesnelerin yer değişiklikleridir. Ancak burada vurgulanması gereken nokta, karakter ve nesnelerin betimlenmesiyle yetinilmemesi gerektiğidir. Yetkin betimlemeci, iletişim amacına ve erek kitleye uygun metin üretmeli; anlatının izlenmesini sağlayacak biçimde ama işlemleme yükünü çok fazla arttırmadan, yeri ve zamanı, olayları, olaylar arasındaki neden-sonuç ilişkilerini ve karakterlerin amaç ve duygularını da betimlemelidir ( Güven, 2018).

Bunun için yapılması gereken görme engelli bireylere bilginin aktarımını kolaylaştıracak ve bağımsız hareket etme imkanı sağlayacak araç ve ortamlar sunmaktır. Sinema ve televizyon üzerine yapılan son çalışmalar göstermedir ki, sesli betimlemenin başarısı görsel materyallerin kelimelere nasıl aktarıldığına bağlıdır. Ve görme engelli bireylerin sesli betimlenin alternatif yöntemlerine olumlu yanıtlar verdiğini göstermektedir. Udo, Acevedo ve Fels tarafindan 2009 yilında yapılan ve öznel, duygusal kelime dağarcığını kullanan alternatif bir sesli betimleme canlı bir Hamlet üretimi için hazırlanmıştır. Sahnenin hissini yeniden yaratmaya odaklanan çalışma, Sesli betimle, geleneksel bir Shakespeare formunda yazılmış ve Horatio'nun bakış açısından anlatılııştır. Yapılan çalışma izler kitle tarafindan etkili ve eğlenceli bulunmuştur. Fryer ve Freeman tarafindan 2012 yllinda yapılan çalışmada ise iki farklı metin tasarlanmıştır. İlk metin geleneksel yöntemler ile tasarlanmış, karakterler, konumlar, zaman ve koşullar, kolayca tanımlanamayan sesler, ekran üstü işlemler ve ekran bilgileri Ofcom yönergelerine göre hazırlanmıştır. Diğer senaryoya ise 'sinematik' adı verilmiştir. Film terminolojisini dahil ederek hazırlanan senaryo Ofcom kılavuzu ile kasitlı olarak çelişmektedir. Gösterimden sonra alınan geri bildirimler kullanıcılarının \% 70'inin 'sinematik' betimlemeyi tercih ettiği görülmüştür. Benzer şekilde Szarkowska tarafindan 2013 yılında yapılan 
Çelen Özer, A., Kalkan, B., \& Gürses, G. (2020). An inclusive model suggestion in audio-visual media design in sampling of public ads: Is accessible media possible? Journal of Human Sciences, 17(1), 246-271. doi:10.14687/ihs.v17i1.5936

çalışma da benzer sonuçlar vermektedir. Sanatsal sinemayı tanımlamak için "AUTEUR AÇIKLAMASI" kendi kontrol ve kendi bakış açısını filmlerini yansıtan yönetmen olarak tanımlanan yeni bir sesli betimleme yöntemini savunan Szarkowska'nın senaryosu filmin senaryosuna çok yakındır. Metafor, neolojizmler ve duygu açıklamalarının bolca olduğu çalışmada izleyici görüşleri olumlu ve yararlı bulunmuştur (Walczak \& Fryer, 2017).

Bu çerçevede görülmektedir ki, görsel- işitsel medya ürünleri olan televizyon ve sinema metin yapılarının anlatı yapıları çerçevesinde ele alınması ve geleneksel sesli betimleme yöntemlerinin dışında, sinematografik dil ile yapılandırılması alımlayıcı kitle tarafından olumlu karşılanmaktadır. Sinematografik dilin yapılandırılması sürecinde üzerinde önemle durulması gereken bileşenler; mekansal-zamansal ayarlar, hareketler, iletişim ve karakter tanımlarıla bağlantılı fillerin, karakterlerin ruh haliyle bağlantılı sıfatların, mekansal-zamansal ayarlara ve karakterlere bağlı isimler ve zarflardır. (Matamala,2018)

Görsel- işitsel medya ürünleri tasarımında salt çeviri teknikleri dışında kullanıcı beklentilerine dönük olarak yapılacak çalışmaların önemi her geçen gün artmakta ve evrensel tasarım ilkeleri çerçevesinde erişilebilirlik değil, kullanılabilirlik kavramı ile de tanımlanmasını zorunlu hale getirmektedir.

\section{Yöntem}

Kamu spotlarının görme engelli bireyler tarafindan da erişilebilir olarak tasarlanmadığ1 varsayımının sınandığı çalışmada AFAD tarafindan Afetlere Hazırlık Yılı projesi kapsamında hazırlatılan Temmuz- Ağustos- Eylül- Ekim- Kasım- Aralık 2019'da yayına giren "Afetlere Hąır Ol" spotları anlatı analizi ile incelenmiştir.

Anlatı analizi, hikâyesi olan metinleri veya görsel verileri yorumlamak için bir dizi analitik yöntem anlamına gelir. Anlatım yöntemleri, insanların hayatlarını organize etmeye ve anlamlandırmaya yardımcı olmak için hikâyeler anlattı̆̆ı ve hikâyelerin işlevsel amaçlı olduğu olduğu ortak varsayımından hareket etmektedir. Anlatım analizi, anlatı içeriğine veya yapıya odaklanmalarına dayanarak iki farklı yaklaşımla incelenmektedir. Tematik versiyon bir hikayenin ne olduğunu sorgularken, yapısal versiyon belirli iletişsimsel amaçlara ulaşmak için bir hikayenin nasıl oluşturulduğunu sormaktadır (Figgou \& Pavlopoulos, 2015).

Anlatı araştırmaları narratoloji çalışmalarına dayanmaktadır. Narratoloji gündelik hayatın içindeki anlatılar yerine anlatıların evrensel yapısının soyut tanımlamalarını ortaya koymaya çalışmaktadır. Labov ve Waletzky'nin çalışmaları anlatı için evrensel bir yapının ortaya konulması noktasında önemli görülmektedir. Labov'un çalışmalarına göre tam yapılanmış bir anlatı yapısında; özet, hikayedeki zaman, olay örgüsü, karakterler ve mekanı içeren oryantasyon bölümü, kronolojik olarak olayların aktarıldığı karmaşıklaştırıcı eylem, olayların anlatıcı için geldiği anlamın ortaya konulduğu değerlendirme, çözüm ve tekrardan bu ana taşıyan bitiş bölümüdür. (Şah, 2018). Labov'un modelinin ana noktaları ilk olarak 1972'de "Anlatım Sözdiziminde Deneyim Dönüşümü" başlıklı bir makalede yayınlanmıştır. Bu makalede Labov, bir anlatının altı ana parçası olarak gördüklerini tanıtır ve açıklar. Her bölümü, anlatı kalıplarını analiz etmek, tekrar eden temaları ve fikirleri tanımak için kullanılan bir araç olarak tartısır. Labov'un altı bileşenin belirli bir sırada görünmesi gerekmez ve her biri çeşitli şekillerde mevcut olabilir, bu bileşenler son analizde de dikkate alınmaktadir. (Essays UK, 2018).

Görme engelli bireyler için kapsayıcı tasarımlara görsel- işitsel medya ürünü olan kamu spotlarının tasarımında yer verilmediği varsayımı üzerine inşa edilen çalışmada Riesmann'ın anlatı analizi ile kamu spotları incelenmiştir. Labov ve Gee'nin yaklaşımlarını kullanan Riessman, yapısal analizi tartışmaktadır. Labov'un yaklaşımını kullanan Riesmann, Labov'un altı bileşenin verilerin analizini nasıl kolaylaştırdığını söylemektedir. Riesmann'ın Labov'a eleştirisi, prototip hikaye formuna uymayan ancak anlatı gibi hissettiği, metin örneklerini sunması ile başlamaktadır. Riessman, tematik, yapısal, diyalog / performans ve görsel olmak üzere bir anlatım analizi tipolojisi sunmaktadır. Anlatı verileri ile çalışmak için somut stratejiler sunan Riesmann, epistemolojik 
Çelen Özer, A., Kalkan, B., \& Gürses, G. (2020). An inclusive model suggestion in audio-visual media design in sampling of public ads: Is accessible media possible? Journal of Human Sciences, 17(1), 246-271. doi:10.14687/jhs.v17i1.5936

konuların, veri türlerinin ve anlatı tanımının, verinin analiz edilme ve yorumlanma şekli üzerindeki etkisini vurgulaması açısından önemlidir (Duque, 2009).

Çalışmada Huzur Mahallesi sakinlerinin günlük yaşam pratiklerine odaklanan, anlatı formatında giriş-gelişme ve sonuç bölümleri içeren kamu spotunda, olay örgüsü, karakterler ve karakterlerin işlevleri incelenmiştir. Riesmann'ın görsel analizi temel alınarak yapılandırılan çalışma, görsel analiz sadece görüntülerin nasıl ve neden üretildiğini değil, aynı zamanda görüntülerin katılımcılarla nasıl yeniden üretime girdiğini ve anlatının işbirlikçi yapısını da ortaya koymaktadır. İncelenen altı "Afetlere Hazırlıklı Ol!" kamu spotunun anlatı yapısı çözümlenmeye çalışılmıştır. Anlatı yapısı çözümlenirken "anlatıdaki kişiler kimler, bu kişilerin, anlatıdaki işlevi nedir, bu kişiler, anlatıda ne yapıyorlar, niçin yapıyorlar ve sonuçlar ne?" sorularına araştırmacılar dışında görsel iletişim, görsel- işitsel çeviri ve yazınsal iletişim alanında çalışan altı farklı uzmandan cevaplanması istenmiş, gelen cevaplar doğrultusunda veri analiz süreci başlamıştır. Nitel araştırmalarda geçerlilik ve güvenilirlik tartışmaları halen devam ederken, Riesmann anlatı araştırmalarının geçerliliğinin, gelecekteki çalışmaları bilgilendirme ve katılımcıları güçlendirerek sosyal değişime katkıda bulunma yeteneklerinde yattığını ileri sürmektedir. Bu çerçevede çalışma AFAD tarafindan Afetlere Hazırlık Yılı projesinin zihinsel dönüşümü hedefleyen bir proje olması nedeni ile toplumun tüm kesimlerine ulaşması noktasında önemli görülmektedir.

\section{Araştırmanın Amacı}

Çalısmanın amacı; görme engelli bireylerin görsel- işitsel medya ürünlerine erişiminde anlatı yapısının önemini, sesli betimleme kriterleri çerçevesinde kamu spotları ele alınarak açıklamaktır. Araştırma kapsamında karakterler ve işlevleri, Labov ve Riesmann'ın anlatı analizi bileşenleri çerçevesinde incelenmiş ve "Kamu spotunda anlatı oluşturulurken mekansal-zamansal bileşenler, hareketler, karakter tanımlarıyla bağlantılı fiilleri betimleyen görsel materyaller, görme engelli bireyler için kelimelere aktarılmakta mıdır?” sorusuna yanıt aranmaktadır.

\section{Araştırmanın Sınırlılıkları}

Yapılan bu çalışma AFAD'ın Afetlere Hazırlık Yılı projesi kapsamında Temmuz 2019'da yayına girmeye başlayan 6 kamu spotu ile sinırlıdır. Türkiye'nin afet haritaları incelendiğinde konunun önemi ve toplumun farklı kesimleri tarafından da farkındalık çalışmalarına duyulan ihtiyaç ilgili kamu spotlarının analiz birim olarak seçilmesinin nedenidir. 2019 yllında başlayan proje kapsamında Afetlere Hazırlık Yılı çalışmaları 12 ayda, 12 temayı kapsayan etkinlikler toplumda önlem alma kültürünü gerçekleștirmek için önemli bir adım olarak görülmektedir.(www.hazirol.gov.tr) Bu çerçevede hazırlanan kamu spotları geniş kitlelere ulaşma konusunda etkili bir araç olarak görülmektedir. Basılı ve ses dosyaları olarak tasarlanan farkındalık çalışmaları araştırma kapsamı dışında tutulmuştur. Ses dosyalarının görsel- işitsel tasarımlar olmaması ve basılı malzemelerin de anlatı yapısını ortaya koyma sürecinde sınırlı olması nedeni ile kapsam dışında bırakılmışır.

\section{Çalışmanın Anlatı Analizi Bölümü}

Çalışmanın analiz birimi, İçişleri Bakanlığı ve AFAD işbirliği ile hazırlanan, RTÜK web sayfasında kamu spotları bölümünde yer alan, televizyon kanalları ve sosyal medyada yer alan, afetlerde yaşanması muhtemel olumsuzluklara karşı izleyiciyi bilinçlendirmeyi amaçlayan kamu spotlandır. İncelenen kamu spotları deprem, sel, afet çantası, zorunlu deprem sigortası, toplanma ve acil durum alanları ve binaların depreme dayanıklılı̆ı konularını içermektedir. Hazırlanan kamu spotlanı birbiri ile bağıntılı alı kısa filmden oluşmaktadır. Filmlerde çoğunlukla dış ses kullanılarak heterodiegetik yani öykü dışı anlatı yapısı kullanılmıştır. Altı kamu spotunda da çoğunlukla verilmek istenen mesaj görüntülere ya da diş sese yüklenmiştir. İzleyicinin ikna edilebilmesi için önce görüntülerle mesajın yüklendiği bir anlatı yapısı kurulmuş sonrasında spot bitiminde dış ses aracıllğıyla verilmek istenen mesaj motto söz ve grafik yazı ile izleyiciye aktarılmaya çalışılmış ve bu 
Çelen Özer, A., Kalkan, B., \& Gürses, G. (2020). An inclusive model suggestion in audio-visual media design in sampling of public ads: Is accessible media possible? Journal of Human Sciences, 17(1), 246-271. doi:10.14687/jhs.v17i1.5936

şekilde ikna yoluyla istenen bilincin oluşması hedeflenmiştir. İzleyenle bildirişimsel temas kuran, açıklama ve yorumlamaları düzenleyen anlatıcı dış ses olarak yapılandırılmıştır. Anlatıcı konumundaki dış ses her kamu spotunda görsel ve sözel anlatı yapısının sonunda kamu spotunun verdiği ders, mesaj ya da amacıyla ilgili yorumlar yapmaktadır.

İlk kamu spotunda, olası bir depremin yaşanacak kayıplarla huzuru nasıl bozduğu anlatılmaktadır. İkinci kamu spotunda doğal afetlerden sel riskine değinilmiş ve yaşanılan yerle ilgili risk bilgisinin öğrenilmesinin önemine değinilmiştir. Üçüncü kamu spotunda afet çantasında bulundurulması gereken malzemeler ve afet çantasının önceden hazırlanmasının önemine vurgu yapılmıştır. Dördüncü spotta zorunlu deprem sigortasının gerekliliği ele alınmıştır. Beşinci kamu spotunda toplanma ve acil durum alanlarının halk tarafindan bilinmesinin önemine değinilmektedir. Altıncı ve son kamu spotu depremde can ve mal kaybına uğramamak için yaşanılan binaların depreme dayanıklılığının tespitinin yaptırılması üzerinde durmaktadır.

Kamu spotlarının hepsinde bütünlük oluşturması açısından tek bir fon müziği kullanılmıştır. Kamu spotlarında, “ Afetlere Hazır Ol” ve "Huzur Sokağı Hep Huzurlu Kalsın” olmak üzere iki motto söz kullanılmıştır.

\section{Bulgular}

\section{Kamu Spotunda Kronoloji ve Nedensellik}

Anlatılar, kamu spotlarında giriș, gelişme ve sonuç bölümlerine göre tasarlanmıştur. Çalıșma kapsamında incelenen kamu spotlarında olaylar bir nedensellik bağlantısı içerisinde ilerlemektedir. Afetlerde can ve mal kaybı yaşanmaması için önlem alınması vurgulanmış ve dramatize edilerek afetlere vurgu yapılmıştır. İncelenen kamu spotlarındaki olaylar, birbiriyle mantıksal olarak sıralanmıştır. Örneğin birinci kamu spotunda, mahallerinde huzur ve mutluluk içinde yaşamını sürdüren mahalle sakinlerinin deprem felaketi sonucunda oluşan can ve mal kayıpları ile huzurları bozulur. Kamu spotu olarak hazırlanan kisa filmde "Huzur Mahallesi Hep Huzurlu Kalsın” vurgusu yapılarak deprem için önlem alınması gerektiği vurgulanmaktadır. İkinci kamu spotu olarak hazırlanan filmde; yine huzur mahallesinde yaşayan bir vatandaşın sel riskine karşı can yeleği giymesi konu olarak ele alınmış ve mahallenin sel riski taşımadığından yola çıkılarak yaşanılan yerle ilgili afet risk bilgisinin öğrenilmesi gerektiği üzerinde durulmuştur. Üçüncü kamu spotunda; Huzur mahallesinde oturan bir anne ve kızın dışarı çıkmak için çantalarını hazırlamalarından yola çıkılmış ve afet çantası hazırlamanın önemine değinilerek afet çantasında yer alacaklar gösterilmiştir. Dördüncü filmde; huzur sokağında merdivenlerde gitar çalıp, "depremler oluyor içimde" şarkısını söyleyen gençleri dinlerken zorunlu afet sigortası hakkında konuşan iki mahalle sakini yer almış ve maddi zarara uğramamak için sigorta yaptırmanın önemi vurgulanmıştır. Beşinci kamu spotu; huzur mahallesinde yaşayan bir baba ve kızın mahalle esnafindan alış veriş yaptıktan sonra yolda yürürken toplanma alanını gösteren levhayı görmelerini konu almış ve acil durumlarda toplanma alanı olarak belirlenen yerlerin bilinmesinin önemine değinilmiştir. Altınca kamu spotu ise arabasına önem verdiği için periyodik bakıma götüren birinden yola çıkılarak, yaşanılan binaların depreme dayanıklılığının tespitinin yaptırılmasının önemi üzerinde durulmuştur.

\section{Kamu Spotlarında Ahenk ve Uygunluk}

İncelenen kamu spotlarında "Huzur Mahallesi" adı verilen tek bir mekândan yola çıkılarak afetler için önlem alınması gerektiği bilgilendirmesi yapılmıştır. Altı kamu spotunun da afetlerle ilgili farkındalık yaratmaya dayalı bilgilendirici dramatize olayları huzur mahallesi sakinleri üzerinden aktarılmıştır. Kamu spotları aynı mekânda geçen olayları anlatarak birbirini tamamlayan kısa filmler şeklinde hazırlanmışır. Böylece kamu spotlarının birbiri ile ahenkli, tutarlı ve uyumlu olması sağlanmıştır. Kamu spotları dramatize edilmiş olayları içerse de gerçek yaşamda her an karşılaşılabilecek afete dayalı olaylanı konu olarak ele aldığı için gerçeğe de uygundur. Gerçekleşmesi 
Çelen Özer, A., Kalkan, B., \& Gürses, G. (2020). An inclusive model suggestion in audio-visual media design in sampling of public ads: Is accessible media possible? Journal of Human Sciences, 17(1), 246-271. doi:10.14687/ihs.v17i1.5936

muhtemel olaylar olduğu için izleyiciye olay örgüsünün güvenilirliği ve inandırıc1luğ1 da söz konusu olmaktadır.

Kamu spotlarının birbiri ile uyumunu arttırıcı bir diğer özellik de seçilen fon müziğidir. Afetlere hazır olmak ve önlemleri almak gerektiğine değinen altı kamu spotunda da tek bir mahalle mekânı ve tek bir fon müziği kullanılarak birbiriyle uyumlu, izleyicinin aklında daha fazla kalıcı spotlar oluşturulması amaçlanmıştır.

İncelenen kamu spotlarında, sorulara anlatı kuramı çerçevesinde yanıtlar aranmış ve elde edilen bulgular aşağıda detaylı olarak açıklanmışır.

\section{Kamu Spotu 1: Huzur Mahallesi Hep Huzurlu Kalacak Mi?}

Anlatıdaki insanlar kim?

Kamu spotu olarak hazırlanan kisa filmde önce huzur mahallesi tabelası ve sonrasinda mahallede mutlu ve huzurlu bir hayat süren mahalle sakinleri yer alıyor.

Bu kişilerin, anlatıdaki işlevi nedir?

Huzur mahallesi sakinleri bir mahallede bir arada mutlu ve huzurlu yaşayan insanları temsil etmektedir.

Bu kişiler, anlatıda ne yapıyorlar?

İlk olarak huzur mahallesindeki huzurlu ve mutlu yaşamı göstermek için sokakta yürüyen, işine, okula, alışverişe giden, dükkânını açarken komşuları ile selamlaşan, kafesinde sıcak çayını ve kurabiyelerini hazırlayan, evinde ailecek kahvaltı yapan mahalle sakinlerinin günlük mutlu ve huzurlu yaşamları verilmektedir. Bu görüntüler fon müziği eşliğinde konuşma sesi kullanmadan verilmiştir. Hiç umulmadık bir anda meydana gelen deprem evlerde ve iş yerlerinde hasara yol açar ve mahalle sakinlerinin de fiziksel ve maddi zarar görmelerine sebep olur. Mahalle bir anda savaş alanına döner. Bu görüntülerde de yine fon müziği ve panik havasını yaratmak için depremde kırılan, devrilen eşya sesleri ve çı̆̆lık atan insan sesleri efekt ses olarak kullanılmıştır.

Niçin yapiyorlar?

Huzur mahallesinin birbiri ile iyi anlaşan bir arada yaşamaktan mutlu insanlardan meydana geldiğini göstermek için herkesin birbiri ile güzel ilişkiler kurduğu gösterilmektedir. Sonrasında olan deprem ile bu huzurlu ve mutlu yaşam birden yerle bir olur. "Huzur Mahallesi Hep Huzurlu Kalacak mı" dış ses ile "Hep Huzurlu Kalalım Diye Afetlere Hazırlık Yılı Başlıyor" motto sözü grafik yazı olarak ekrana gelir.

Sonuçlar ne?

Kurulan anlatı yapısında kişiler ve olay örgüsü ile afetlerin insanların huzurlu yaşantısını ve birbirleri ile süregiden mutlu ilişkilerini nasıl yerle bir edeceği gösterilmeye çalışılmıştır. Burada önemli olan izleyicinin de sahip olduğu ya da olmayı istediği huzurlu ve mutlu bir mahalle yaşamının olay örgüsüne konu olan depremle nasıl yerle bir olduğunu görülmesi, ikna olunması, mutlu ve huzurlu olan yaşamın devamlılı̆̆ için afetlere karşı gerekli tedbirlerin öğrenilerek alınması, farkına varılmasıdır. Hazırlanan kamu spotunun hedefi insanların huzurla ve mutlulukla sürdürdükleri yaşamlarının ve ilisskilerinin yaşanacak bir afetle yok olacağını bir kez daha görerek anlamasıdır. Hazırlanan kamu spotu ile izleyenlerin depremle ilgili farkındalığının arttırılması, alınacak önlemlerin, yapılması gerekenlerin bilinmesi ve yerine getirilmesi amaçlanmaktadır. Hazırlanan filmde fon müziği, ses efektleri ve grafik yazı için dış ses kullanılmıştır. Mahalle sakini olarak yer alan kişilerin konuşmaları ya da söze dayalı diyaloglar bulunmamaktadır.

\section{Kamu Spotu 2: Yaşanılan Yerin Olası Afet Tehlikeleri Hakkında Bilgilenme}

Anlatıdaki insanlar kim?

Kamu spotu olarak hazırlanan kısa filmde huzur mahallesinde yaşayan ve mahalle kahvesinde kapı önünde oturup sohbet eden kişiler ve evinden turuncu can yeleği takarak çıkan Ahmet adındaki mahalle sakini yer alıyor.

Bu kişilerin, anlatıdaki işlevi nedir? 
Çelen Özer, A., Kalkan, B., \& Gürses, G. (2020). An inclusive model suggestion in audio-visual media design in sampling of public ads: Is accessible media possible? Journal of Human Sciences, 17(1), 246-271. doi:10.14687/jhs.v17i1.5936

Ahmet sel felaketinden korktuğu için tedbir amacıyla turuncu can yeleğini takarak sokağa çıkan ama mahallesindeki sel tehlikesi konusunda bilgi sahibi olmayan biridir. Kahve kapısının önünde oturan ve çay içip, sohbet edenler ise mahallenin afet tehlikelerini araştırıp, öğrenen ve sel felaketi riskinin mahalle için geçerli olmadığını bilenlerdir. Bu kişiler Ahmet’i mahallenin afet riskleri hakkında bilgi sahibi olması konusunda uyarırlar.

Bu kişiler, anlatıda ne yapıyorlar?

Huzur mahallesi kahvesinin dişında masada oturan ve çay içip sohbet eden kişiler apartman kapısından turuncu can yeleği ile çıan Ahmet’i görünce gülerler. Çay getiren kahveci can yeleğini niçin taktı̆̆ını sorar. Ahmet çok yağmur yağacağını ve sel için önlem aldığını söyler. Masada oturan mahalle sakini Ahmet'e "kendi mahalleni tanımıyor musun? Mahallede sel riski”" yok ki der. Dış ses "önce yaşanılan yerin afet tehlikelerini öğrenelim, hazırlıklarımızı ona göre yapalım” der ve "Hep huzurlu kalalım diye afetlere hazır ol" motto sözü dış ses ve grafik yazı ile birlikte verilerek kamu spotu sona erer. Kamu spotunda yaşanılan yerin afet riskleri hakkında önceden bilgi sahibi olmak gerektiği mesajı sözlü diyaloglar ve diş ses ile izleyiciye aktarılıyor.

Niçin yapiyorlar?

Ahmet turuncu can yeleğini sele karşı önlem olarak takıyor. Mahallenin sel riski taşımadı̆̆ını bilmiyor. Ahmet'in mahallenin sel riski taşımadığını bilmediğini anlayan mahalle sakinleri onu bu konuda araştırma yapması ve mahallenin afet riskleri hakkında bilgi sahibi olması konusunda uyarıyor. Bu kamu spotunun amacı; toplumda afetler ve yaşadıkları yerin afet riskleri hakkında bilgi sahibi olması gerektiğinin farkındalığının oluşturulması.

Sonuçlar ne?

Ahmet mahallenin afet risklerini bilmediği ve yağacak yağmurların mahallede sel oluşturacağını düşündüğü için turuncu yelek önlemi alıyor ama mahalleliye karşı komik duruma düşüyor. Çünkü diğerleri mahallenin sel riski taşımadığını biliyor. Yaşanılan yerin afet risklerini bilip, buna göre önlem almanın gerektiğini izleyiciye veriyor ve yaşanılan yerin afet risklerinin araştırılması için farkındalık oluşturulmaya çalışlıyor.

\section{Kamu Spotu 3: Afet Çantasının Hazır Bulundurulması}

Anlatıdaki insanlar kim?

Ilk olarak huzur mahallesi tabelası ve sokakta yürüyen mahalle sakinleri görüntüde veriliyor. Sonrasında mahallede evlerinde dışarı çıkmak için çantalarını hazırlayan anne ve küçük kızı görüntüye geliyor.

Bu kişilerin, anlatıdaki işlevi nedir?

Anne ve küçük kızı dışarı çıkacakları çantalarını hazırlıyor. Anne kendi için önemli olan makyaj malzemelerini çantasına koyuyor. Annesinin çantasına koyduklarını gören küçük kız da sırt çantasına önemli gördüğü boya kalemlerini, kitaplarını ve oyun hamurlarını koyuyor. Anne ve kız sokağa çıkmak için kendilerince gerekli ve önemli çanta malzemelerini hazırlıyor ama afet çantası hazırlamayı akıllarına getirmiyor. Dış ses bu görüntü üzerine can sağlığı için afet çantalarının önceden hazırlanması ve altı ayda bir kontrol edilmesi gerektiğini vurgulayarak bu konuda izleyicide farkındalık oluşturmaya çalışıyor.

Bu kişiler, anlatıda ne yapıyorlar?

Anne ve küçük kızı çantalarını hazırlarken görülüyor. Anne kendi için önemli olan makyaj malzemelerini çantasına koyuyor. Annesinin çantasına koyduklarını gören küçük kız da sırt çantasına boya kalemlerini, kitaplarını ve oyun hamurlarını koyuyor. İkisi de dışarı çıkmaya hazır birbirine gülümserken dış ses "Çantalar Hazır Harika! Peki, Afet Çantanız Hazır mı?” diye soruyor. Kadının yüzünde önce tedirgin düşünen bir ifade beliriyor ve sonrasında üzgün bir şekilde hayır anlamında başını iki yana sallıyor. Dış ses tekrar konuşmaya başlıyor ve "canınız sağ olsun demek isterdik ama afetlerde hayatın bir parçası, altı ayda bir on dakikanı afetlere hazırlanmak için ayır ki canın sağ olsun!" diyor. Bu sözler sırasında ekranda ailenin Afet çantasını hazırlaması veriliyor. Baba Afad ilk yardım çantasını Afad sırt çantasının içine yerleştiriyor. Masanın üzerinde el fenerleri, su 
Çelen Özer, A., Kalkan, B., \& Gürses, G. (2020). An inclusive model suggestion in audio-visual media design in sampling of public ads: Is accessible media possible? Journal of Human Sciences, 17(1), 246-271. doi:10.14687/ihs.v17i1.5936

şişeleri, konserve yiyecek ve bisküviler görülüyor. Anne çantaya koyulması için babaya battaniye verirken küçük kız da oyuncak tavşanını babaya uzatıyor.

Niçin yapiyorlar?

Huzur mahallesinde yaşayan anne ve küçük kızı sokağa çıkmadan önce hazırlık olarak çantalarına lazım olacağını ve kullanacaklarını düşündükleri eşyalarını koyuyor. Çantalarını hazırlamayı unutmayan anne ve küçük kızı olası bir afette kullanacakları afet çantasını hazırlamayı ihmal ediyor. Dış ses kullanılarak izleyiciye afet çantası hazırlamanın ve bu çantaları altı ayda bir kontrol ederek içindekileri yenilemenin önemi ve gerekliliği sözlü olarak, hazırlanacak afet çantasına neler konulması gerektiği görüntü olarak veriliyor. Hazırlanan kamu spotunun amacı toplumun afetlere hazır olunması için önceden yapılması gerekenlerden birisi olan afet çantasını hazırlama ve altı ayda bir bu çantadakileri kontrol edip yenileme konusunda bilinçlenmesi ve farkındalığın oluşturulması.

Sonuçlar ne?

Sokağa çıkarken çanta hazırlamayı ve ihtiyaçları olacak malzemeleri çantalarına koymayı unutmayan anne ve kızı afet çantası hazırlamayı aklına getirmiyor ve ihmal ediyor. Afetlere hazırlık için önceden afet çantası hazırlamayı unutan anne ve kızı üzerinden izleyiciye canınız sağ olsun diye afetlere hazır olun mesajı veriliyor ve toplumun afetler konusunda önceden bilinçlenmesi ve gerekli önlemleri alması için farkındalık oluşturuluyor.

\section{Kamu Spotu 4: Afet ve Acil Durum Toplanma Alanları}

Anlatıdaki insanlar kim?

Afetlere hazırlık yılı kapsaminda hazırlanan Huzur Mahallesi hep Huzurlu kalsın mottosu ile tasarlanan kamu spotlarının dördüncüsü, afet ve acil durum toplanma alanları konusunda farkındalık oluşturmayı amaçlamaktadır. Huzur Mahallesi ve sokakta yürüyen insanlarla görüntü açıldıktan sonra, Huzur Mahallesi’nde yaşayan baba ve kız ile dış ses anlatı özneleri olarak tanımlanmaktadır.

Bu kişilerin, anlatıdaki işlevi nedir?

Afet ve acil durum toplanma alanları konusunda farkındalık oluşturmak için tasarlanan kamu spotunda, günlük yaşantıda temel ihtiyaçlanı gidermek için bilinen mekanlara karşıllk, afet ve acil ve toplanma alanlarının bilinmediği varsayımı üzerinden hareket edilmekte ve farkındalık oluşturmak için baba ve kızın pastaneden çıkış anları üzerine dış sesin sorusu ile farkındalık oluşturulmaya çalışılmaktadır.

Bu kişiler, anlatıda ne yapıyorlar?

Huzur mahallesinde Huzur pastanesinden mutlu bir şekilde çıan baba- kızın görüntüleri üstüne dış ses farkındalı̆̆ı oluşturmak için çatışmayı soru ile kurmaktadır. Afet ve acil toplanma alanlarını bilip, bilmediklerini soran dış sesin ardından Afet ve acil toplanma alanları konusunda bilgiye sahip olan kız çocuğu, babasını acil ve afet toplanma alanına yönlendirmekte ve dış ses görüntüler akarken konu ile ilgili bilgileri aktarmaktadır. Baba ve kızın diyaloglar ile anlatıda yer almazken, jest ve mimikler kurucu öğe olarak dikkat çekmektedir. Afet ve acil durum toplanma alanı tabelasının altına geldiklerinde de farkındalık jest ve mimikler ile verilmekte dış ses konunun önemine dikkat çekerken, mekân, karakter tanımlamasına yer vermemektedir.

Niçin yapiyorlar?

İlgili kamu spotunda diğer kamu beş kamu spotunda kurulan "Huzur Mahallesi hep huzurlu kalacak mi?" anlatı yapısı Afet ve Acil Durum Toplanma Alanları kamu spotunda da devam ettirilmektedir. Amaç toplanma alanları konusunda farkındalığın artırılmasıdır.

Sonuçlar Ne?

Afetlere hazırlık yılı kapsamında hazırlanan Afet ve Acil Toplanma Alanları farkındalık oluşturulmasını amaçlayan kamu spotu, günlük ihtiyaçlarımızı karşılamak için detayları ile bilinen mekânsal alanlara karşıllk afet ve acil durum toplanma alanlarının bilinmediğini ortaya koymakta ve 
Çelen Özer, A., Kalkan, B., \& Gürses, G. (2020). An inclusive model suggestion in audio-visual media design in sampling of public ads: Is accessible media possible? Journal of Human Sciences, 17(1), 246-271. doi:10.14687/jhs.v17i1.5936

farkındalığı sağlamaktadır. İlgili kamu spotu Huzur pastanesi, toplanma alanı tabelası, baba- kızın jest ve mimikleri, 2D grafik göstergeleri ile anlatı yapısını güçlendirmektedir.

\section{Kamu Spotu 5: Afet Sigortas1}

Anlatıdaki İnsanlar Kim?

Afet sigortasının önemine dikkat çekilen kamu spotunda anlatının karakterleri 1999 Van depreminde zarar gören bir adam, komşusu, Huzur Mahallesi’nde müzik yapan gençler, deprem sigortası yaptıran insanlar ve dış sestir.

Bu kişilerin, anlatıdaki işlevi nedir?

Afet sigortasının önemine dikkat çekilen kamu spotunda anlatı "depremler oluyor içimde" şarkısını söyleyen gençler, anlatı yapısının kurulmasına ve Van depreminde evine kaybeden adamın komşusu ile olan diyaloğuna geçiş için kullanılmıştır. Müzik yapan gençlerin kamu spotunda bir diğer işlevi, Huzur mahallesinde huzurun temsili olarak herkesin mutlu bir yaşam sürdüğü, gençlerin caddelerinde müzik yaptığı bir mekânsal alanı temsil etmesidir. Dış ses diğer kamu spotlarında olduğu gibi deprem sigortasının önemi ve bilgi aktarıcısı olarak tanımlanmıştır. Huzur mahallesinde DASK standı başında görülen mahalle sakinleri, anlatının güçlendirilmesi için kullanılmış ve sigortalama sürecinin ulaşılabilirliği ve önemi konusunda farkındalık mahalle sakinlerinin verdiği önem ile gösterilmiştir.

Bu kişiler anlatıda ne yapıyorlar?

Kamu spotunda anlatı yapısının kurucu unsuru müziktir. Gençler sokak müziği yapmakta ve seslendirdikleri parça depreme vurgu yapmaktadır. 1999 Van depreminde evi zarar gören adam deprem sigortası sayesinde maddi bir kayıp yaşamadıklarını belirterek, komşusuna acılarının azda olsa azaldığını belirtmektedir. Diğer kamu spotlarında olduğu dış ses deprem sigortasının önemini aktarmakta ve kurucu unsur olan müzikle anlatı arasındaki yapıyı kurmaktadır. Deprem Sigortası ( DASK) standı önünde sigorta yaptıran mahalle sakinleri ise dışs sesin mesajını desteklemektedir.

Niçin yapiyorlar?

Anlatı yapısı deprem sigortasının önemini vurgulamak ve farkındalı̆̆ artırmak için müzik ve diyaloglar ile tasarlanmıştır. Ana karakterler arasındaki diyalog müziği desteklerken, müzik dış sesin mesajının kodlanmasına kaynaklık etmektedir. Dış sesin "depremler şarkılarda kalsın" mottosu kamu spotunun odak noktasını oluşturmaktadır. DASK standı önünde sigorta yaptıran mahalle sakinleri destekleyici görüntü olarak kullanılmış, dış ses metni görüntülerin üzerine gelmiştir. Görüntülerin dış ses metni ile bağlantısı bulunmamaktadır.

Sonuçlar Ne?

Afetlere hazırllk yilı kapsaminda hazırlana seri kamu spotlarından biri olan deprem sigortası farkındalık metni, deprem sigortasının önemini depremi yaşamış ve sigorta sayesinde maddi kayba uğramamış bir depremzede üzerinden yapılandırmaktadır. Gerçek yaşam verileri üzerinden kurgulanan anlatı yapısı deprem sigortasının önemini vurgulamak noktasında dikkat çekmektedir. Diğer kamu spotları ile anlatı yapısının kurulması noktasında değerlendirildiğinde, görsel unsurlar yerine diyalog ve müziğin yapıda kullanılmış olması yönü ile diğerlerinden ayrılmaktadır.

\section{Kamu Spotu 6: Afetlere Hazırlık}

Anlatıdaki İnsanlar Kim?

Afetlere hazırlık kamu spotu, diğer kamu spotları gibi huzur Mahallesi insan görüntüler ile açılmaktadır. Anlatı yapısının ana karakteri, huzur mahallesinde yaşayan erkek bir mahalle sakinidir. Karakter jest ve mimikleri ile anlatı yapısında tasarlanırken, dış ses anlatıcıdır.

Bu kişilerin anlatıdaki işlevi nedir?

Afetlere hazırlık konusunda farkındalık yaratmak için tasarlanan kamu spotunda ana karakter afetlere hazırlık konusunda her hangi bir girişimi o güne kadar olmamış bir mahalle sakinini tanımlamakta ve dış sesin konu hakkında dikkati çekeceği anlatı öznesi olarak dikkat çekmektedir.

Bu kişiler anlatıda ne yapiyorlar? 
Çelen Özer, A., Kalkan, B., \& Gürses, G. (2020). An inclusive model suggestion in audio-visual media design in sampling of public ads: Is accessible media possible? Journal of Human Sciences, 17(1), 246-271. doi:10.14687/jhs.v17i1.5936

Afetlere hazırlık konusunda bilgisi olmayan mahalle sakini ana karakter, arabasının olağan bakımlarını yaptırmaktadır. Dış ses bu noktada devreye girerek, aracının bakımını yaptıran mahalle sakinine afetlere hazırlık yaptırıp yaptırmadığını sormaktadır. Ses unsuru karakterin yapılandırılmasında kullanılmamış, sözsüz iletişim aracı olarak vücud dili karakterin cevaplarını vermektedir. Afetlere hazırlık yapmadığını belirten ana karakterin cevabından sonra dış ses afetlere hazırlı̆̆ı önemine vurgu yapmakta ve kamu spotunun anlatı yapısında farklı bir mekana geçiş yapılmaktadır. Ana karakterin evinde kolon hasar tespiti yapan bir uzmanla çekilen görüntüler üzerine dış sesin önemi ifade eden metni gelmektedir. Görüntünün dış ses metni ile bağlantısı bulunmamaktadir.

Sonuçlar Ne?

Afetlere hazırlık konusunda farkındalık yaratmayı amaçlayan kamu spotu, anlatı yapısını nesneler üzerinden inşa etmekte, nesneler verdiğimiz önem kadar kendimize ne kadar önem verdiğimizi sorgulatmakta ve afetlere hazırlık yapmanın önemine dikkat çekmektedir. Farkındalık oluşturmak için hazırlanan kamu spotu diğer kamu spotlarında olduğu gibi huzur ve mutlu bireyler kavramları çerçevesinde bilginin görüntü ile kodlandığı mesajlar ile alıcı kitleye ulaşmaktadır.

\section{Sonuç}

Engelli bireylerin görsel- işitsel medya araçlarına erişimine ilişkin 2019 yllinda yürürlüğe giren 30915 sayılı "Sağırların, İşitme Ve Görme Engellilerin Yayın Hizmetlerine Erişiminin İyileştirilmesine İlişkin Usul Ve Esaslar Hakkında Yönetmelik" çerçevesinde görsel- işitsel medya araçlarının erişilebilir tasarım ilkelerine göre yapılandırılması önemli hale gelmiştir. Erişilebilir görselişitsel medya araçları tasarım ilkeleri bu çalışma kapsamında görme engelli bireyler ile sınırlandırılmaktadır. Bu çerçevede görme engelli bireylerin görsel- işitsel medya ürünlerine erişiminde sesli betimleme yöntemi kuşkusuz en etkili yöntem olarak dikkat çekmektedir.

Sesli betimleme, bir dış sesin, olayın geçtiği mekânı, zamanı, karakterleri ve görsel- işitsel üründeki sessiz gelişen olayların betimlenmesi ve görsel malzeme ve duyguların izleyiciye aktarılmasıdır. Sesli betimleme ile özel olarak kurgulanan görsel- işitsel medya ürününe görme engelli bireylerin erişimi sağlanmaktadır. Medya ürünlerinin artan çeşitliliği ve 21. Yüzyılda engelli kültürünün yeniden inşası çalışmaları ile görme engelli bireylere yönelik çeviri çalışmalarının da tanımı değişmiş ve görsel- işitsel çevirinin geleneksel çeviriye göre farklı bilgilerle çalıştŭg gerçeği önemli bir unsur olarak dikkat çekmektedir. Bu çerçevede görsel- işitsel medya ürünleri olan televizyon ve sinema metin yapılarının anlatı yapıları çerçevesinde ele alınması ve geleneksel sesli betimleme yöntemlerinin dışında, sinematografik dil ile yapılandırılması alımlayıcı kitle tarafindan olumlu karşılanmakta ve kullanıcı beklentilerini ölçmek için yapılan araştırmalar göstermektedir ki evrensel tasarım ilkeleri çerçevesinde sadece erişilebilir medya ürünleri tasarımı değil, kullanılabilir tasarım anlayışı da erişilebilirlik çalışmalarında yerini almıştır.

Araştırma kapsamında incelenen televizyon kamu spotlanı da görsel- işitsel medya ürünleri olarak erişilebilirlik ve kullanılabilirlik kriterleri ile tasarlanması gereken anlatı yapılanıdır. Kamu spotlarr, sosyal pazarlama ve sosyal reklam birbirine benzer özelliklere sahiptir. Ortak özellik kamu yararı hedeflemeleridir. Kitle iletişim araçları kullanılarak toplumdaki bireyleri etkilemek ve topluma fayda sağlayacak tutum ve davranışı sağlamak amaçlanmaktadır. Bilgilendirme ve ikna bu programların çıkış noktasını oluşturmaktadır. Sosyal pazarlama ve kamu spotlarında konular bireylerin ve toplumun sağllk, güvenlik teknoloji, aile, toplumsal ve sosyal yaşama dayalı kurallar gibi kar amacı gütmeyen ve kamusal farkındalığı arttırmayı amaçlayan bilgilendirici ve eğitici içeriklerden oluşmaktadır. Bu içerikler yapılandırılırken Çalışmada Huzur Mahallesi sakinlerinin günlük yaşam pratiklerine odaklanan kamu spotlarının anlatı formatında nasıl işlendiği ve karakterler ile karakterlerin işlevleri incelenmiştir. Riesmann'ın görsel analizi temel alınarak yapılandırılan çalışma, görsel analiz sadece görüntülerin nasıl ve neden üretildiğini değil, aynı zamanda görüntülerin katılımcılarla nasıl yeniden üretime girdiğini ve anlatının işbirlikçi yapısını da ortaya koymaktadır. İncelenen "Afetlere Hazırlıklı Ol!" kamu spotunda anlatı yapısı çözümlenirken anlatı kuramları 
Çelen Özer, A., Kalkan, B., \& Gürses, G. (2020). An inclusive model suggestion in audio-visual media design in sampling of public ads: Is accessible media possible? Journal of Human Sciences, 17(1), 246-271. doi:10.14687/jhs.v17i1.5936

çerçevesinde yer alan sorulara cevap aranmıştır. "Anlatıdaki kişiler kimler, bu kişilerin, anlatıdaki işlevi nedir, bu kişiler, anlatıda ne yapıyorlar, niçin yapıyorlar ve sonuçlar ne?" sorularına araşturmacılar dışında görsel iletişim, görsel- işitsel çeviri ve yazınsal iletişim alanında çalışan altı farklı uzmandan cevaplanması istenmiş, gelen cevaplar doğrultusunda veri analiz süreci başlamıştur. Elde edilen bulgular çerçevesinde incelenen kamu spotlarında Huzur Mahallesi’nde yaşayan mahalle sakinleri ve mahalle yaşamı afetler arasındaki bağ huzur ve mutluluk kavramları ile kurulmaya çalışılmıştır. Yapılandırılan anlatılarda çatışma afet karşısında ne yapacağını bilmeyen mahalle sakinleri ile kurulmaya çalışılmış ve görsel imaj, jest, mimik ve hareketlerle desteklenmiştir. $\mathrm{Bu}$ noktada izlenen altı kamu spotunun da görme engelli bireyler için tasarlanmadığı görülmektedir. Afetlere karşı hazırlıklı ol! Mottosunu destekleyen tüm unsurların görsel yapım öğeleri ile verilmiş olması, kamu spotlarına görme engelli bireylerin erişimini olanaksız kılmaktadır. Kamu spotları süreleri açısından değerlendirildiğinde; deprem videosunun 35 saniye, sel videosunun 36 saniye, afet çantası videosunun 38 saniye, afet ve acil toplanma alanlar1 videosunun 32 saniye, afetlere hazırlıklı ol videosunun 30 saniye, deprem sigortası videosunun 36 saniye olduğu görülmektedir. İncelenen kamu spotlarında sesli betimleme kullanılmamış, geleneksel çeviri teknikleri dışında anlatı yapılarını betimleyen dramatik metinlere de yer verilmemiştir.

Kamu spotu 1. Deprem / 35"

\begin{tabular}{|l|l|}
\hline $\begin{array}{l}\text { Gösterge türü/ } \\
\text { sunuluş }\end{array}$ & Kamu spotunda yer alan başlıca göstergeler \\
\hline $\begin{array}{l}\text { Görsel-sözsüz } \\
\text { (görüntü, fotoğraf, } \\
\text { jestler) }\end{array}$ & $00.00-00.21$ müzik- ses efektleri \\
\hline $\begin{array}{l}\text { Görsel-sözel (ekler, } \\
\text { afişler, harfler, } \\
\text { bilgisayar }\end{array}$ & $00.21-00.23$ seslendirme \\
ekranlarındaki & $00.23-00.28$ grafik tasarım (AFAD- Bakanlık logoları) \\
mesajlar, gazete & $00.28-00.35$ görüntü -seslendirme \\
başlıkları) & \\
\hline
\end{tabular}

Deprem videosunda 21 saniye boyunca Huzur Mahallesi sakinlerinin günlük yaşam pratikleri ve depremin başladığı an anlatılırken, görüntüleri açıklayıcı metin olmadığı dikkat çekmektedir. Sel, afet çantası, toplanma alanları, deprem sigortası ve afetlere hazırlıklı ol videolarında da anlatı yapıları görsel yapım öğeleri ile kurulurken, bu öğelerin betimlemeleri yapılmamaktadır.

Kamu spotu 2. Sel/ 36"

\begin{tabular}{|l|c|}
\hline $\begin{array}{l}\text { Gösterge türü/ } \\
\text { sunuluş }\end{array}$ & Kamu spotunda yer alan başlıca göstergeler \\
\hline $\begin{array}{l}\text { Görsel-sözsüz } \\
\text { (görüntü, fotoğraf, } \\
\text { jestler) }\end{array}$ & $00.00-00.03$ Müzik/ ses efekti- kahkaha \\
\hline $\begin{array}{l}\text { Görsel-sözel (ekler, } \\
\text { afişler, harfler, } \\
\text { bilgisayar } \\
\text { ekranlarındaki } \\
\begin{array}{l}\text { mesajlar, gazete } \\
\text { başlikları) }\end{array}\end{array} \quad \begin{array}{c}00.04-00.22 \text { diyalog } \\
\text { ortam diyalog) } \\
00.26-00.32 \text { görüntü/ seslendirme } \\
00.33-00.36 \text { grafik tasarım- seslendirme }\end{array}$ \\
\hline
\end{tabular}


Çelen Özer, A., Kalkan, B., \& Gürses, G. (2020). An inclusive model suggestion in audio-visual media design in sampling of public ads: Is accessible media possible? Journal of Human Sciences, 17(1), 246-271. doi:10.14687/ihs.v17i1.5936

Kamu spotu 3. Afet çantas1/38”

\begin{tabular}{|l|l|}
\hline $\begin{array}{l}\text { Gösterge türü/ } \\
\text { sunuluş }\end{array}$ & Kamu spotunda yer alan başlıca göstergeler \\
\hline $\begin{array}{l}\text { Görsel-sözsüz } \\
\text { (görüntü, fotoğraf, } \\
\text { jestler) }\end{array}$ & $00.00-00.00 .14$ \\
\hline $\begin{array}{l}\text { Görsel-sözel (ekler, } \\
\text { afişler, harfler, }\end{array}$ & $\begin{array}{l}00.19-00.22 \text { müzik- jest } \\
\text { bilgisayar }\end{array}$ \\
$\begin{array}{l}\text { ekranlarındaki } \\
\text { mesajlar, gazete } \\
\text { başlıkları) }\end{array}$ & 00.25 - 00.25 seslendirme- jestler \\
\hline
\end{tabular}

Kamu spotu 4. Toplanma Alanı/32"

\begin{tabular}{|l|l|}
\hline $\begin{array}{l}\text { Gösterge türü/ } \\
\text { sunuluş }\end{array}$ & Kamu spotunda yer alan başlıca göstergeler \\
\hline $\begin{array}{l}\text { Görsel-sözsüz } \\
\text { (görüntü, fotoğraf, }\end{array}$ & $\begin{array}{l}00.00-00.05 \text { MÜZİK } \\
\text { jestler) }\end{array}$ \\
\hline $\begin{array}{l}\text { Görsel-sözel (ekler, } 00.17 \text { jest kız çocuğu babasına işaret eder } \\
\text { afişler, harfler, }\end{array}$ & 00.26 tabela görsel \\
$\begin{array}{l}\text { bilgisayar } \\
\text { ekranlarındaki }\end{array}$ & 00.15 SESLENDİRME \\
mesajlar, gazete & 00.30 seslendirme görsel \\
başlikları) & \\
\hline
\end{tabular}

Kamu spotu 5. Afetlere Hazırlıklı Ol/ 30"

\begin{tabular}{|l|l|}
\hline $\begin{array}{l}\text { Gösterge türü/ } \\
\text { sunuluş }\end{array}$ & Kamu spotunda yer alan başlıca göstergeler \\
\hline $\begin{array}{l}\text { Görsel-sözsüz } \\
\text { (görüntü, fotoğraf, } \\
\text { jestler) }\end{array}$ & $\begin{array}{l}00.00-00.08 \text { görsel- müzik } \\
00.15-00.16 \text { jest/ müzikte değişim }\end{array}$ \\
\hline $\begin{array}{l}\text { Görsel-sözel (ekler, } \\
\text { afişler, harfler, }\end{array}$ & $00.08-00.19$ seslendirme \\
bilgisayar & $00.20-00.26$ görüntü değişikliği/ seslendirme \\
ekranlarındaki & $00.27-00.29$ grafik tasarım \\
mesajlar, gazete & \\
başlikları) & \\
\hline
\end{tabular}


Çelen Özer, A., Kalkan, B., \& Gürses, G. (2020). An inclusive model suggestion in audio-visual media design in sampling of public ads: Is accessible media possible? Journal of Human Sciences, 17(1), 246-271. doi:10.14687/jhs.v17i1.5936

Kamu spotu 6. Deprem Sigortas1/36”

\begin{tabular}{|l|c|}
\hline $\begin{array}{l}\text { Gösterge türü/ } \\
\text { sunuluş }\end{array}$ & Kamu spotunda yer alan başlıca göstergeler \\
\hline $\begin{array}{l}\text { Görsel-sözsüz } \\
\text { (görüntü, fotoğraf, } \\
\text { jestler) }\end{array}$ & $00.00-00.08$ görsel- müzik \\
\hline $\begin{array}{l}\text { Görsel-sözel (ekler, } \\
\text { afişler, harfler, }\end{array}$ & $00.00-00.28$ müzik yapan çocuklar \\
bilgisayar & $00.28-00.29$ diyalog/ müzik ses/ müzik yapan çocukların görüntüsü \\
ekranlarındaki & üstüne \\
mesajlar, gazete & $00.29-00.32$ diş ses/ görüntü değişikliği \\
başlikları) & $00.32-00.36$ grafik tasarım/ diş ses \\
\hline
\end{tabular}

Görsel- işitsel medya ürünlerinin evrensel tasarım ilkelerine göre tasarlanması ve herkes için erişilebilir ve kullanılabilir olması için kapsayıcı tasarımların yapılması tüm medya ürünleri için önemli olmasına karşın afetler gibi toplumun tüm kesimleri tarafindan bilinç düzeyini artırmaya yönelik kamu spotlarında daha da önemli hale gelmektedir. Kapsayıcı tasarımların görsel- işitsel medya ürünlerinde kullanımına ilişkin literatür taraması ve incelenen kamu spotlarının yapım öğelerine dayanarak oluşturulan model metin deprem kamu spotu için tasarlanmıştır. Model metin yapılandırılırken Labov'un anlatı bileşenleri kullanılmış ve heterodiegetik ( öykü dışı anlatı yapısı) yap1 tercih edilmiştir.

\section{Çalışmanın Örnek Kapsayıcı Tasarımını İçeren Anlatı Modeli 1.}

\begin{tabular}{|c|c|}
\hline $\begin{array}{l}\text { Gösterge türü/ } \\
\text { sunuluş }\end{array}$ & Kamu spotunda yer alan başlıca göstergeler \\
\hline $\begin{array}{l}\text { Görsel-sözlü } \\
\text { (görüntü, } \\
\text { fotoğraf, jestler) }\end{array}$ & LMA \\
\hline $25 ”$ & $\begin{array}{l}\text { Müzik } \\
\text { Huzur Mahallesi’nde gün, tüm sıcaklığı ile başlamıştı. Terzi Mehmet } \\
\text { Bey dükkanının kapısını umutla açarken, Ayşe Hanım çoktan kahvaltıy1 } \\
\text { hazırlamış, Huzur Pastanesi’nde poğaçalar firından yeni çımışt. O } \\
\text { büyük gürültü tam da o anda başladı. }\end{array}$ \\
\hline \multirow[t]{2}{*}{$7 "$} & $\begin{array}{l}\text { Devrilen eşyalar, dükkanlarından kaçmaya çalışan insanlar, patlayan } \\
\text { camlar. Minik Ada, yerde bulduğu rüzgar gülü ile yaralıların arasında } \\
\text { yavaş yavaş yürürken, tek bir soru geçiyordu, korku dolu düşüncelerinde, } \\
\text { Huzur Mahallesi hep huzurlu kalacak mıydı? }\end{array}$ \\
\hline & $\begin{array}{l}\text { Grafik+ son kare } \\
\begin{array}{l}\text { Huzur Mahallesi hep huzurlu kalsin diye, afetlere hazırlık y1lında afetlere } \\
\text { hazır ol! }\end{array}\end{array}$ \\
\hline
\end{tabular}


Çelen Özer, A., Kalkan, B., \& Gürses, G. (2020). An inclusive model suggestion in audio-visual media design in sampling of public ads: Is accessible media possible? Journal of Human Sciences, 17(1), 246-271. doi:10.14687/jhs.v17i1.5936

\section{Çalışmanın Örnek Kapsayıcı Tasarımını İçeren Anlatı Modeli 2.}

\begin{tabular}{|c|c|}
\hline $\begin{array}{l}\text { Gösterge türü/ } \\
\text { sunuluş }\end{array}$ & Kamu spotunda yer alan başlıca göstergeler \\
\hline $\begin{array}{l}\text { Sözel eleman } \\
\text { (diyalog, } \\
\text { monolog, müzik, } \\
\text { seslendirme) }\end{array}$ & \\
\hline $\begin{array}{l}\text { Sözsüz eleman } \\
\text { (müzik, ses } \\
\text { efektleri, sesler) }\end{array}$ & \\
\hline $\begin{array}{l}\text { Görsel-sözsüz } \\
\text { (görüntü, } \\
\text { fotoğraf, jestler) }\end{array}$ & AÇILMA \\
\hline $1335^{\prime \prime}$ & 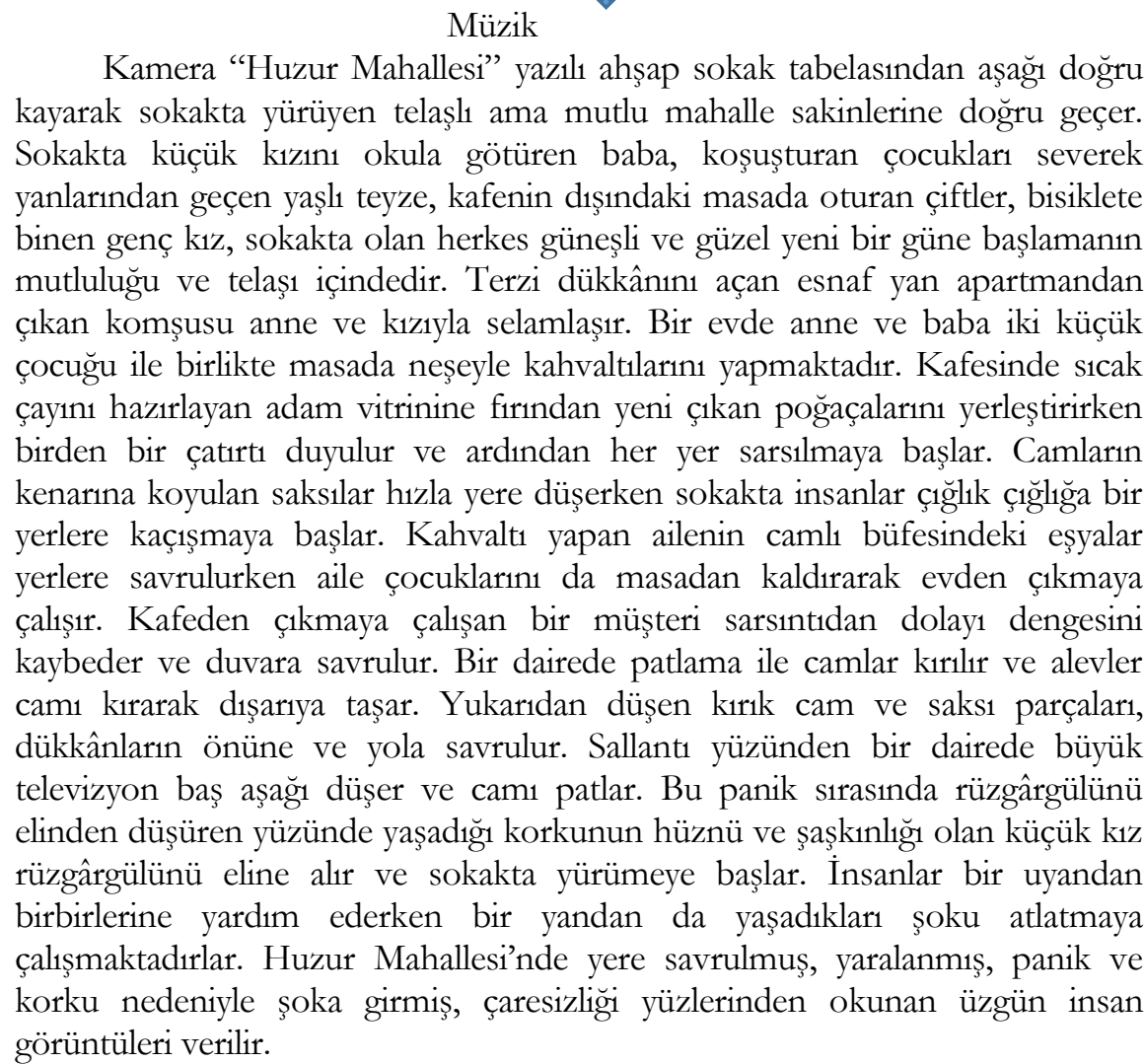 \\
\hline $\begin{array}{c}\text { Görsel-sözel } \\
\text { 3" }\end{array}$ & $\begin{array}{l}\text { 00.21- } 00.23 \text { seslendirme } \\
\text { Dış ses: “Huzur Mahallesi hep huzurlu kalacak mı?” } \\
\text { Grafik yazı sokak görüntüsünün üzerinde akar. } \\
\text { 00.23- 00.28 grafik tasarım ( AFAD- Bakanlık logoları) } \\
\text { Türkiye Cumhuriyeti İçişleri Bakanllğı ve AFAD logolu "Afetlere } \\
\text { Hazırllk Yılı ve Afetlere Hazır Ol” grafik tasarım çerçevede görülür. Dış ses: } \\
\text { Hep Huzurlu Kalalım Diye Afetlere Hazırllk Yılı Başlıor } \\
\text { 00.28- } 00.34 \text { görüntü -seslendirme } \\
\text { Kamera, yangın çıkan evin pencerelerinden görülen dumandan bir ucu } \\
\text { kırılan, yere doğru her an düşecekmiş gibi sarkan Huzur Mahallesi tabelasına } \\
\text { doğru geçer. } \\
\text { Diş ses: Afetlere Hazır Ol } \\
\text { ARMA }\end{array}$ \\
\hline
\end{tabular}


Çelen Özer, A., Kalkan, B., \& Gürses, G. (2020). An inclusive model suggestion in audio-visual media design in sampling of public ads: Is accessible media possible? Journal of Human Sciences, 17(1), 246-271. doi:10.14687/jhs.v17i1.5936

Çalışma kapsamında önerilen modellerden birinci model, görüntüler üzerine yazılan süreye sadık kalınarak hazırlanan metindir. İkinci model ise sesli betimleme kurallarına göre hazırlanmış sahneleri betimleyen modeldir. Ancak bu noktada süre konusunda kısıtlar oluşmaktadır. Yapılan araştırma ve önerilen modeller, sesli betimleme çalışmalarında kullanıcı beklentilerinin en önemli nokta olduğu dikkate alındığında çalışmanın ardından önerilen modellerin ses kayıtlarının alınarak görme engelli bireylerin beklenti ve görüsslerinin alındığ1 araştırmanın öncülü olduğu kabul edilmektedir.

\section{Kaynakça}

Akbulut, S. \& Özgül, H. \& Tezcan, T. (2014). Mevzuattan Uygulamaya Engelli Hakları İzleme Raporu 2013. http://www.engellihaklariizleme.org/tr/files/belgeler/kitap 2013.pdf. adresinden 10.10.2019 tarihinde erişilmiştir.

Benecke, B. (2007). Audio Description: Phenomena of Information Sequencing, EU-HighLel Scientific Conference Series MuTra 2007 - LSP Translation Scenarios: Conference Proceedings, (2).http://euroconferences.info/proceedings/2007 Proceedings/2007 Benecke Bernd.pdf adresinden 12.07.2019 tarihinde erişilmiştir.

Bilgiç, B. (2016). Türkiye'de Kamu Spotu Oluşum Süreci Yayın Politikaları. İletişim Calşsmalarn

Dergisi, 1(2), 25-61. https://dergipark.org.tr/tr/download/article-file/740541 adresinden 05.08.2019 tarihinde erişilmiştir.

Burcu, E. (2017). Türkiye'de Engelli Bireylerin Dezavantajlı Konumlarına Engellilik Sosyolojisinin Eleştirel Tavrryla Bakmak, Toplum Demokrasi, 11 (24), Temmuz-Arallk, s. 107-125. http://toplumdemokresi.org.tr/index.php/tdd/article/viewFile/246/376 adresinden 10.10.2019 tarihinde erişilmiştir.

Chiaro, D. (2009). Issues in Audiovisual Translation, 142-165-(143), http://cw.routledge.com/textbooks/translationstudies/data/samples/9780415396417.pdf. adresinden 05.07.2019 tarihinde erişilmiştir.

Collins, S. \& Missing, C. (2003). Vocal And Visual Attractiness Are Related in Women Anmal Behavour, 2003, 65, 997-1004 doi:10.1006/anbe.2003.2123 https://pdfs.semanticscholar.org/55e5/96216577a6e7d59b5bbbac78d65db9b77b53.pdf adresinden 05.07.2019 tarihinde erişilmiştir.

Çağlar, S.(2012). Engellilerin Erişebilirlik Hakk1 Türkiye'de Erişebilirlikleri. AÜHFD, 61 (2), 541 598. http://dergiler.ankara.edu.tr/dergiler/38/1679/17894.pdf. adresinden 08.09.2019 tarihinde erişilmiştir.

Çakar, C. (2017). İdeolojik Bir Alan Olarak Kamu Spotu İktidar. İstanbul Bilgi Üniversitesi, Sosyal Bilimler Enstitüsü, Yüksek Lisans Tezi.

http://openaccess.bilgi.edu.tr:8080/xmlui/bitstream/handle/11411/1129/\%c4\%b0deolojik\%2 0bir $\% 20$ alan $\% 20$ olarak $\% 20 \mathrm{kamu} \% 20$ spotu $\% 20 \% 20$ iktidar.pdf?sequence $=1 \&$ is Allowed $=$ yadres inden 01/08/2019 tarihinde erişilmiştir.

Çınarlı, S. (2008). "Kamu Hizmetlerinin Yürütülmesinde Engelli Hakları”, Dokuz Eylül Üniversitesi Sosyal Bilimler Enstitüsü Kamu Hukuku Anabilim Dalı Kamu Hukuku Programı doktora tezi.http://acikerisim.deu.edu.tr:8080/xmlui/bitstream/handle/20.500.12397/12281/227273.p df? sequence $=1$ \&is Allowed $=\mathrm{y}$. adresinden 05.08.2019 tarihinde erişilmiştir.

Duque, R. Lyle (2009). Review: Catherine Kohler Riessman (2008). Narrati Methods for the Human Sciences [26 paragraphs]. Forum Qualitati Sozialforschung / Forum: Qualitati Social Research, 11(1), Art. 19, http://nbn-resolving.de/urn:nbn:de:0114-fqs1001193. adresinden 09.12 .2019 tarihinde erişilmiştir.

Erdoğan, İ. \& Alemdar, K.(2010). Öteki Kuram, Yenilenmiş 3. Bask1, http://www.irfanerdogan.com/kuram/sosyalbilim1900.pdf._adresinden 09.10.2019 tarihinde erişilmiştir. 
Çelen Özer, A., Kalkan, B., \& Gürses, G. (2020). An inclusive model suggestion in audio-visual media design in sampling of public ads: Is accessible media possible? Journal of Human Sciences, 17(1), 246-271. doi:10.14687/jhs.v17i1.5936

Erdoğan, İ. (2013). Medya Sosyolojisi. Anadolu Üniversitesi AÖF Yaynlan, Eskişebir, https://sosyolojiden.files.wordpress.com/2015/09/medya-sosyolojisi.pdf. 09.10.2019 tarihinde erişilmiştir.

Essays, U. K. (Nomber 2018). Labov's Model of Narrati Analysis. Retried from https://www.ukessays.com/essays/english-language/labovs-model-narrati-analysis2563.php?vref=1 adresinden 10.09.2019 tarihinde erişilmiştir.

Figgou, L. \& Pavlopoulos, V. (2015). Social Psychology: Research Methods, International Encyclopedia of the Social \& Behavioral Sciences,

https://www.sciencedirect.com/topics/psychology/narrati-analysis adresinden 20.12.2019 tarihinde erişilmiştir.

Gül, İ. I., (2015). Birleşmiş Milletler Engelli Hakları Sözleşmesi, http://secbir.org/images/2015/pdf/metin3.pdf. adresinden 07.09.2019 tarihinde erişilmiştir.

Güven, M. (2018). Sesli Betimleme Araştırmalarında Güncel Yönelimler, http://dad.boun.edu.tr/tr/download/article-file/610719.adresinden 05.07 .2019 tarihinde erişilmiştir.

Hersh, M.(2008). Acessibility and Usability of Virtual Learning Environments, https://ieeexplore.ieee.org/stamp/stamp.jsp?tp=\&arnumber=4561906. adresinden 03.10.2019 tarihinde erişilmiştir.

Hertrich, I. \& Dietrich, S. \& Moos, A. \& Trouvain, J., Ackermann, H. (2009). Enhanced Speech Perception Capabilities in A Blind Listener are Associated with Activation of Fusiform Gyrus and Primary Visual Corte. Neorocase, 15(2):163-70, March 2009.

https://www.researchgate.net/publication/24038657 Enhanced speech perception capabiliti es in a blind listener are associated with activation of fusiform gyrus and primary visual cortex adresinden 16.01.2020 tarihinde erişilmiştir.

Janh, M. (2015). Anlatıbilim: Anlatı Teorisi El Kitabı, Çev. Bahar Dervişcemaloğlu, Dergah Yayınlar, Istanbul.

Jekat, S. J. \& Prontera, D. \& Bale, R.(2015). On the Perception of Audio Description: Deloping a Model to Compare Films and Their Audio Described rsions. Trans-kom ISSN 1867-4844 http://www.trans-kom.eu trans-kom ist eine wissenschaftliche Zeitschrift für Translation und Fachkommunikation. trans-kom 8 [2] (2015): 446-464 Seite 446.

https://digitalcollection.zhaw.ch/bitstream/11475/4942/1/2015_Jekat_On $\% 20$ the $\% 20$ perception $\% 20$ of $\% 20$ audio $\% 20$ description trans-kom.pdf adresinden 12.07 .2019 tarihinde erişilmiştir.

Kızılaslan, A. \& Sözbilir, M.(2017). Görme Yetersizliği Olan Öğrencilerin Bilişsel Becerileri Psikolojik Deneyimleri Üzerine Bir Derleme. Pamukekale University Journal of Social Sciences Institüte ISSN1308-2922 EISSN2147-6985, DOI: 10.30794/pausbed.414613 Research Article. https://dergipark.org.tr/tr/download/article-file/456620 adresinden 12.07.2019 tarihinde erişilmiştir.

Köten, E. \& Erdoğan, B. ( 2014). Engelli Gençler, Sosyal Dişlanma ve İnternet, İstanbul Gelişim Üniversitesi $\quad$ Yaynlar. https://www.academia.edu/13414187/ENGELL\%C4\%B0_GEN\%C3\%87LER SOSYAL D I\%C5\%9ELANMA VE \%C4\%B0NTERNET adresinden 02.07.2019 tarihinde erişilmiştir.

Küçükali, A. (2014). Engellilere Uygulanan Sosyal Politikaların Değerlendirilmesi: Atatürk Üniversitesi Örneği. https://dergipark.org.tr/download/article-file/181083. adresinden 09.08.2019 tarihinde erişilmiştir.

Sandıkçıŏ̆lu, B.(2013 ). "İkna Kuramları", İkna Edici İletişim AÖF e-kitap,/Gǚ http://www.nevoku.com/ikna-edici-iletisim--e-kitap--ikna-edici-iletisim/viewdeck/9a170397e0d4-45ae-bb73-ea0dfed890d2 adresinden 11/10/2019 tarihinde erişilmiştir.

Şahin, H. \& Toker, H. \& Koyuncu, Ö. B. \& Alpöz, E. \& Gedik, Z. \& Kahraman, S. \& Yavuz, M. \& Yılmaz, G. \& Çepiş, A. \& Oral, E.( 2017). Engellilik Etik, Dokuz Eylül Ünirsitesi Yayınlar, http://www.kutuphane.deu.edu.tr/wpcontent/uploads/2017/03/engellilik--etik.pdf adresinden 10/10/2019 tarihinde erişilmiştir. 
Çelen Özer, A., Kalkan, B., \& Gürses, G. (2020). An inclusive model suggestion in audio-visual media design in sampling of public ads: Is accessible media possible? Journal of Human Sciences, 17(1), 246-271. doi:10.14687/jhs.v17i1.5936

Şardağı, E. \& Yılmaz, A. (2017).“Anlatı Kuramı ve Reklamda Kullanımı: Anlatı Analizi Çerçevesinde Bir İnceleme”, Maltepe Üniversitesi Illetisim Fakültesi Dergisi, Güz, 88-133. https://dergipark.org.tr/en/download/article-file/386954 adresinden 09.09.2019 tarihinde erişilmiştir.

Matamala, A. (2018). One short film, different audio descriptions. Analysing the language of audio descriptions created by students and professionals, ONOMÁZEIN 41 (septiembre de 2018): 185 - 207 ONOMÁZEIN 41 (septiembre de 2018): 185-207

DOI: $\quad 10.7764 /$ onomazein.41.04http://onomazein.letras.uc.cl/Articulos/N41/41 4 Matamala.pdf. adresinden 12.07.2019 tarihinde erişilmiştir.

Mora, N. ( 2008)."Medya, Toplum ve Haber Kaynağı Olarak Sembolik Seçkinler”, Uluslararası İnsan Bilimleri Dergisi, 5(1),

https://s3.amazonaws.com/academia.edu.documents/31148473/405-1349-

1PB.pdf?responsecontentdisposition $=$ inline $\% 3 \mathrm{~B} \% 20$ filename $\% 3$ DMedia society and the sy mbolic elites as.pdf\&X-Amz-Algorithm=AWS4-HMAC-SHA256\&X-

AmzCredential=AKIAIWOWYYGZ2Y53UL3A\%2F20191229\%2Fuseast $1 \% 2$ Fs3 $\% 2$ Faws 4 request $\& X-A m z-D a t e=20191229 \mathrm{~T} 115302 Z \& X-A m z-$

Expires $=3600 \& X-A m z-$

$\underline{\text { SignedHeaders }=\text { host } \& X A m z S i g n a t u r e}=$ be0b081ac0da8465e1b1e33e36f88beb531 fa0839f2938e 6e8488cf862c9f406. adresinden 07.10.2019 tarihinde erişilmiştir.

Özgül, H. ( 2015). Tanım, Kapsam ve Geliştirilen Politikalar Düzleminde Türkiye'de Erişilebilirlik. http://secbir.org/images/2015/pdf/metin5.pdf. adresinden 01.10.2019 tarihinde erişilmiştir.

Sözen, M. (2008). “Anlatı Mesafesi-Anlatı Perspektifi Kavramları, Sinematografik Anlatı Ve Örnek

Çözümlemeler”, ZKÜ Sosyal Bilimler Dergisi, Cilt 4, (8),123-145

http://www.acarindex.com/dosyalar/makale/acarindex-1423937147.pdf_adresinden $\quad 06.08 .2019$ tarihinde erişilmiştir.

Synder, J.(2010). American Council of The Blınd's Audio Description Project Audio Description Guidelines and Best Practices September (2010 )- A Work In Progress rsion 3.1 - Ed.Joel Snyder,1-98.http://docenti.unimc.it/catia.giaconi/teaching/2017/17069/files/corsosostegno/audiodescrizioni adresinden 05.07.2019 tarihinde erişilmiştir.

Şah, U. (2018). Anlatı Çalışmaları, Psikoloji Toplum, www.psikolojitoplum.org adresinden

11.12.2019 tarihinde erișilmiştir.

Ünver, H. \& Yamaçlı, R. (2014). Ulaşılabilirlik Kültürü, Düzce Üniversitesi Bilim ve Teknoloji Dergisi Derleme Makalesi. http://www.fbedergi.duzce.edu.tr/article/view/5000067688/5000062876. adresinden 10.10.2019 tarihinde erişilmiştir.

Walzcak,A. \& Fryer, L. (2017). Creative description: The impact of audio description style on presence in visually impaired audiences. British Journal of Visual Impairment Vol. 35(1) 6-17 c The Author(s) 2016 Reprints and permissions: sagepub.co.uk/journalsPermissions.nav DOI: 10.1177/0264619616661603 journals.sagepub.com/home/jvi

Yaren, Ö. (2013).“Sinemada Anlatı Kuramı”, Sinema Kuramlar II, (ed.) Zeynep Özarslan, İstanbul: Su, 2013, 167-192. ISBN : 9786054554119 https://www.academia.edu/4918610/Sinemada Anlat $\%$ C4\%B1 Kuram $\% C 4 \% B 1$ Sinema K uramlar\%C4\%B1 2 Beyazperdeyi Ayd\%C4\%B1nlatan_Kuramlar adresinden 17.01. 2019 tarihinde erişilmiştir.

Yıldız, S., \& Gürler, S.(2018). Görme Engelli Bireylerin Engelli Haklarına Dair Bilgi Düzeylerinin Ölçülmesi Ankara Örneği. Kurkkkale Ünirsitesi Sosyal Bilimler Dergisi (KÜSBD), 8 (1), 241-268. https://dergipark.org.tr/download/articlefile/434442.__adresinden 08.09.2019 tarihinde erişilmiştir.

Birleşmiş Milletler Engelli Hakları Sözleşmesinin Türkçe Tam Metni.

https://www.engelsizerisim.com/detay/bm-engelli-haklari-sozlesmesinin-turkce-tam-metni/. adresinden 02/07/ 2019 tarihinde erişilmiştir. 
Çelen Özer, A., Kalkan, B., \& Gürses, G. (2020). An inclusive model suggestion in audio-visual media design in sampling of public ads: Is accessible media possible? Journal of Human Sciences, 17(1), 246-271. doi:10.14687/jhs.v17i1.5936

Engellilerin Haklarına İlişkin Sözleşme. Nisan 2018.

http://www.esithaklar.org/wpcontent/uploads/2018/08/Ayr $\% \mathrm{C} 4 \% \mathrm{~B} 1 \mathrm{mc} \% \mathrm{C} 4 \% \mathrm{~B} 11 \% \mathrm{C} 4 \% \mathrm{~B} 1 \mathrm{k}-$ Yap $\% C 4 \% B 1$ lmamas $\% C 4 \% B 1--E \% C 5 \% 9$ Fitlik-Hakk\%C4\%B1nda-Genel-Yorum-BM-

No.6.pdf. Adresinden 02/07/2019 tarihinde erişilmiştir.

International Classification of Impairments, Disabilities, and Handicaps, WORLD HEALTH ORGANIZATION (WHO)1980.

https://apps.who.int/iris/bitstream/handle/10665/41003/9241541261 eng.pdf;jsessionid=6821B4139 53E02E153241383A5953ADB? sequence $=1$ adresinden 01.08.2019 tarihinde erişilmiştir.

Kamu Spotları Yönergesi, https://www.rtuk.gov.tr/kamu-spotlari/5029/3985/kamu-spotlariyonergesi.html. adresinden 04/07/2019 tarihinde erişilmiştir.

\section{Extended English Summary}

Structuring the audio-visual media tools in accordance with accessible design criteria has gained importance within the frame of the "Regulation No. 30915 on the Methods and Principles for Improving the Access of Hearing/Sight-Disabled Persons to Broadcasting Services", having been enacted in 2019 in respect of disabled persons' access to audio-visual media tools. Design principles for accessible audio-visual media tools are restricted with sight-disabled persons within the scope of this study. In this context, the audio description doubtlessly comes to the fore as the most effective method in respect of the sight-disabled persons' access to audio-visual media products.

Audio description, audio-visual translation in the fields of movie, or theatre involves a voiceover, which describes the location, time, characters, and silently occurring developments of the incident taking place, and narrates the visuals and feelings conveyed therein at the parts of such works that do not contain any dialogue. Special editing of the voice-over at the parts of cinema movies, video films, everything that may fall within cinematography, as well as those of the theatre plays that do not contain any dialogue by means of audio-visual translation, namely audio description technique for the sight-disabled persons enables the same persons watch such works by themselves. Ever-increasing diversification of the media products, as well as the efforts for the reconstruction of the disability culture in $21^{\text {st }}$ Century brings along changes in the audio description works for the sight-disabled persons, and the fact that audio-visual translation works with knowledge different than that of the conventional translation becomes an important aspect. Within this framework, dealing with the television and cinema textual structures that form the audio-visual media products in terms of narrative theories, and structuring them by the cinematographic language, apart from the conventional audio description methods is deemed as a significant step taken in view of accessibility. In the researches intended for assessing the user expectations, too, not only the notion of designing accessible media products, but also the notion of designing utilizable media products has taken its place in the accessibility studies within the frame of the universal designing principles.

TV PSAs reviewed within the scope of the research are also among the narrative structures that should be designed as being open to the access and use of everyone. Public interest is aimed at by PSAs. It is intended to influence the members of the society, and cause them to adopt such attitudes and behaviors that may bring about social benefit by making use of the mass media. Informing and persuasion form the point of origin of these programs. That is because concrete realization of public interest is possible only by way of marketing ideas so as to bring about respective behavioral changes in the individuals. Subjects of social marketing and PSAs consists of informative and instructive contents in respect of health, security, technology, family, essentials of the social life that are non-profit-making, and intended to raise respective awareness in the individuals, and in the society as well. 
Çelen Özer, A., Kalkan, B., \& Gürses, G. (2020). An inclusive model suggestion in audio-visual media design in sampling of public ads: Is accessible media possible? Journal of Human Sciences, 17(1), 246-271. doi:10.14687/ihs.v17i1.5936

Within this framework, the purpose of the research is to explain the importance of the narrative structure in the sight-disabled persons' access to the audio-visual media products over the PSAs within the frame of the audio description criteria. In the study, the characters and the functions thereof in the narration have been reviewed within the frame of Labov \& Riesmann's narrative analysis constituents, and answer has been sought to the question, " are the spatiotemporal constituents, motions, and the visual materials that depict the actions in connection with character definitions put into words for the sight-disabled persons?". The study is restricted with the 6 PSAs, which have been aired since July 2019 within the scope of AFAD's (Disaster and Emergency Management Presidency) Year of Disaster Preparedness Project. Criticality of the issue that may be discerned upon review of Turkey's disaster maps, as well as the need felt for the awareness-raising works by the people from all social segments is the reason why the respective PSAs have been chosen as the analysis units. The Year of Disaster Preparedness activities carried out in 12 months under 12 themes within the scope of the project launched in 2019 are seen to constitute a significant step being taken towards realizing the intellectual transformation that prioritizes the culture of vigilance (www.hazirol.gov.tr). PSAs having been produced in this respect are considered as effective means to reach larger masses. Since the audio-files are not audio-visual designs, and printed materials are limited in the process of introducing the narrative structure, awareness-raising works that are designed in printed and audio-file forms have been excluded from the scope of the research. While the 6 "Be Prepared for the Disasters!" PSAs are analyzed in terms of their narrative structures, answers to the questions, "Who are the persons in the narrative? What are their functions in the narrative? What do these persons do in the narrative? Why do they do these things? What are the outcomes of them?" are sought after. Upon having the respective confirmed also by six different experts serving in the fields of visual communication, audio description, and narrative communication, other than the researchers, the data analysis process has been initiated in parallel with the answers received. In the PSAs reviewed within the frame of the findings at hand, the relation between the residents of the Huzur (Peace) Quarter and their lives therein and the disasters has been attempted to be linked by such concepts as peace and happiness. In the structuring of the narratives, the conflict has been attempted to be staged by residents not knowing what to do in the face of disaster, and visually reinforced by relevant images, gestures, mimics, and acts. At this point, it is understood that, all six PSAs reviewed have not been designed for sight-disabled persons.

Apart from its importance for causing the audio-visual media products designed in accordance with the universal design principles as being accessible and utilizable for everyone, performing comprehensive designs for all media products has become even more important in case of PSAs, which are intended to raise awareness among people from all social segments in respect of such critical issues as disasters. The model text, having been drawn up on the basis of the literature search on the use of comprehensive designs in the audio-visual media products and the production elements of the PSAs reviewed, has been designed for the PSA on the earthquakes. Labov's narrative constituents have been made use of, and heterodiegetic (off-narrative narration structure) structure has been preferred while constructing the model text. 